\title{
Anthropogenic perturbation of the carbon fluxes from land to ocean
}

\author{
Pierre Regnier etal.
}

\begin{abstract}
A substantial amount of the atmospheric carbon taken up on land through photosynthesis and chemical weathering is transported laterally along the aquatic continuum from upland terrestrial ecosystems to the ocean. So far, global carbon budget estimates have implicitly assumed that the transformation and lateral transport of carbon along this aquatic continuum has remained unchanged since pre-industrial times. A synthesis of published work reveals the magnitude of present-day lateral carbon fluxes from land to ocean, and the extent to which human activities have altered these fluxes. We show that anthropogenic perturbation may have increased the flux of carbon to inland waters by as much as $1.0 \mathrm{PgC}^{-1} \mathrm{r}^{-1}$ since pre-industrial times, mainly owing to enhanced carbon export from soils. Most of this additional carbon input to upstream rivers is either emitted back to the atmosphere as carbon dioxide $\left(\sim 0.4 \mathrm{PgC} \mathrm{yr}^{-1}\right)$ or sequestered in sediments $\left(\sim 0.5 \mathrm{PgCyr}^{-1}\right)$ along the continuum of freshwater bodies, estuaries and coastal waters, leaving only a perturbation carbon input of $\sim 0.1 \mathrm{Pg} \mathrm{C} \mathrm{yr}^{-1}$ to the open ocean. According to our analysis, terrestrial ecosystems store $0.9 \mathrm{Pg} \mathrm{C} \mathrm{yr}^{-1}$ at present, which is in agreement with results from forest inventories but significantly differs from the figure of $1.5 \mathrm{Pg} \mathrm{Cyr}^{-1}$ previously estimated when ignoring changes in lateral carbon fluxes. We suggest that carbon fluxes along the land-ocean aquatic continuum need to be included in global carbon dioxide budgets.
\end{abstract}

$\mathrm{D}$ uring the past two centuries, human activities have greatly modified the exchange of carbon and nutrients between the land, atmosphere, freshwater bodies, coastal zones and the open ocean $^{1-9}$. Together, land-use changes, soil erosion, liming, fertilizer and pesticide application, sewage-water production, damming of water courses, water withdrawal and human-induced climatic change have modified the delivery of these elements through the aquatic continuum that connects soil water to the open ocean through rivers, streams, lakes, reservoirs, estuaries and coastal zones, with major impacts on global biogeochemical cycles ${ }^{10-14}$. Carbon is transferred through the aquatic continuum laterally across ecosystems and regional geographic boundaries, and exchanged vertically with the atmosphere, often as greenhouse gases (Box 1).

Although the importance of the aquatic continuum from land to ocean in terms of its impact on lateral C fluxes has been known for more than two decades ${ }^{15}$, the magnitude of its anthropogenic perturbation has only recently become apparent ${ }^{8,12,16-18}$. The lateral transport of $\mathrm{C}$ from land to sea has long been regarded as a natural loop in the global C cycle unaffected by anthropogenic perturbations. Thus, this flux is at present neglected in assessments of the budget of anthropogenic $\mathrm{CO}_{2}$ reported, for instance, by the Intergovernmental Panel on Climate Change (IPCC) or the Global Carbon Project ${ }^{19-23}$. Quantifying lateral C fluxes between land and ocean and their implications for $\mathrm{CO}_{2}$ exchange with the atmosphere is important to further our understanding of the mechanisms driving the natural C cycle along the aquatic continuum ${ }^{24,25}$, as well as for closing the $\mathrm{C}$ budget of the ongoing anthropogenic perturbation.

Data related to the $\mathrm{C}$ cycle in the aquatic continuum from land to ocean are too sparse to provide a global coverage, with insufficient water sampling, poorly constrained hydrology and surface area extent of various ecosystems, and few direct $p \mathrm{CO}_{2}$ and other carbon-relevant measurements ${ }^{26,27}$. Global box models have been used to explore the magnitude of these fluxes and their anthropogenic perturbations, but the processes remain highly parameterized $^{7}$. The current generation of three-dimensional Earth system models includes the coupling between the $\mathrm{C}$ cycle and the physical climate system, but ignores lateral flows of C (and nutrients) altogether $^{28}$. Major challenges in the study of $\mathrm{C}$ in the aquatic continuum include the disentangling of the anthropogenic perturbations from the natural transfers, identifying the drivers responsible for the ongoing changes and, ultimately, forecasting their future evolution, for example, by incorporating these processes in Earth system models. Resolving these issues is not only necessary to refine the allocation of greenhouse-gas fluxes at the global and regional scale, but also to establish policy-relevant regional budgets and mitigation strategies ${ }^{29}$.

The term 'boundless carbon cycle' was introduced to designate the present-day lateral and vertical C fluxes to and from inland waters only ${ }^{17}$. Here, we extend this concept to all components of the global $\mathrm{C}$ cycle that are connected by the land-ocean aquatic continuum (Box 1) and discuss possible changes relative to the natural C cycle by providing new separate estimates for the present day and the anthropogenic perturbation. This distinction is important because, in some instances, bulk fluxes have been compared with perturbation fluxes, such as the net land $\mathrm{C}$ sink of anthropogenic $\mathrm{CO}_{2}$, which may cause confusion ${ }^{17,30}$. Here we deal with the total C fluxes, but do not systematically distinguish between inorganic and organic, as this is still poorly known at the global scale for several of the components of the land-ocean continuum. However, we do highlight the exact chemical composition where it is sufficiently well constrained. Supplementary Table S1 is a compilation of the major flux estimates from the literature and estimated in this paper with a measure of confidence involving transfer of $\mathrm{C}$ from one global domain to another. A brief justification of our proposed estimate for each of these fluxes is also provided.

\section{Contemporary estimates of lateral carbon fluxes}

In this section, we derive contemporary estimates of the carbon fluxes along the continuum of the spectrum of land-ocean aquatic systems. We first look at the $\mathrm{C}$ transports involving inland waters and then consider their links to $\mathrm{C}$ flows through estuaries and the coastal ocean and beyond. 


\section{Box 1 | Land-ocean carbon flux concepts}

The land-ocean aquatic continuum. This can be represented as a succession of chemically and physically active biogeochemical systems, all connected through the continuous water film that starts in upland soils and ends in the open ocean. Carbon is transferred along this continuum. These systems are often referred to as filters, because carbon is not only transferred, but also processed biogeochemically and sequestered in sediments or exchanged with the overlying atmosphere as greenhouse gases (Fig. 1a).

The pre-industrial land-ocean loops. Lateral carbon transfer through the aquatic continuum was already active under preindustrial conditions and the boundless carbon cycle consists of two loops. The organic carbon loop starts with the lateral leakage of some of the organic carbon that is fixed into the terrestrial biosphere by photosynthesis. This carbon is then transferred horizontally through aquatic channels down to the coastal and open ocean where $\mathrm{C}$ is returned to the atmosphere as $\mathrm{CO}_{2}$. The inorganic loop is driven by the land-based weathering of silicate and carbonate rocks that consumes atmospheric $\mathrm{CO}_{2}$, and the subsequent transport of the weathering products of cations, anions and dissolved inorganic carbon to the ocean, where part of the $\mathrm{CO}_{2}$ is returned to the atmosphere through ocean carbonate sediment formation (a process that increases $p \mathrm{CO}_{2}$ in seawater). The other part is returned by volcanism. Both loops are generally assumed to have been in a quasi-steady-state initial condition in pre-industrial times, that is, they were globally balanced at the millennial timescale.

Anthropogenic perturbation of the lateral carbon fluxes. Human perturbations to the lateral carbon fluxes have moved the boundless carbon cycle away from this global balance, causing imbalances in the fluxes and stocks, such as the $\mathrm{C}$ inputs from soils to inland water systems, the strength of the air-water $\mathrm{CO}_{2}$ exchange fluxes, the $\mathrm{C}$ storage reservoirs and, thus, the chain of lateral $\mathrm{C}$ fluxes through the successive filters. Because the reconstruction of lateral carbon fluxes entails large uncertainties, we only attempt quantification for pre-industrial and present-day (past decade) conditions. We thus regard the change in the fluxes and stocks since the pre-industrial period as the anthropogenic perturbation, and treat the average preindustrial conditions as the natural contribution.

Inland waters. The present-day bulk $\mathrm{C}$ input (natural plus anthro-

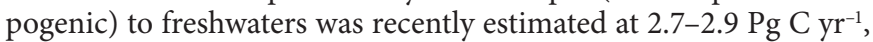
based on upscaling of local C budgets ${ }^{17,26}$. This input is composed of four fluxes. The first and largest one is soil-derived $\mathrm{C}$ that is released to inland waters, mainly in organic form (particulate and dissolved), but also as free dissolved $\mathrm{CO}_{2}$ from soil respiration ${ }^{31}\left(F_{1}\right.$ in Fig. 1a and Table 1). The flux is evaluated at $1.9 \mathrm{Pg} \mathrm{C} \mathrm{yr}^{-1}$, by subtracting, from a total median estimate of $2.8 \mathrm{Pg} \mathrm{C} \mathrm{yr}^{-1}$, the smaller contributions from the other three fluxes: chemical weathering $\left(F_{2}\right)$, sewage $\left(F_{4}\right)$ and net $\mathrm{C}$ fixation $\left(F_{5}\right)$. The soil-derived $\mathrm{C}$ flux is part of the terrestrial ecosystem $\mathrm{C}$ cycle (Box 1) and represents about $5 \%$ of soil heterotrophic respiration $\left(\mathrm{FT}_{7}\right)$. Current soil respiration estimates neglect the $\mathrm{C}$ released to inland waters. A downward revision of the estimate of soil heterotrophic respiration to account for the soil C channelled to inland freshwater systems would nevertheless remain within the uncertainty of this flux ${ }^{32}$.

The second flux involves the chemical weathering of continental surfaces (carbonate and silicate rocks). It is part of the inorganic (often called 'geological') C cycle (Box 1) and causes an additional $\sim 0.5 \mathrm{Pg} \mathrm{C} \mathrm{yr}^{-1}$ input to upstream rivers ${ }^{33-37}\left(F_{2}\right)$. About two-thirds of this $\mathrm{C}$ flux is due to removal of atmospheric $\mathrm{CO}_{2}$ in weathering reactions $\left(F_{3}\right)$ and the remaining fraction originates from chemical weathering of $\mathrm{C}$ contained in rocks. The pathway for chemical weathering is nevertheless largely indirect with most of the $\mathrm{CO}_{2}$ removed from the atmosphere being soil $\mathrm{CO}_{2}$, having passed through photosynthetic fixation. Weathering releases $\mathrm{C}$ to the aquatic continuum in the form of dissolved inorganic $\mathrm{C}$, mainly bicarbonate, given that the average $\mathrm{pH}$ is in the range of $6-8$ for freshwater aquatic systems ${ }^{38}$. In contrast to soil-derived organic C, it is assumed that $\mathrm{C}$ derived from rock weathering will not degas to the atmosphere during its transfer through inland waters ${ }^{39}$.

The third flux represents the $\mathrm{C}$ dissolved in sewage water originating from biomass consumption by humans and domestic animals $\left(F_{4}\right)$, which releases an additional $\sim 0.1 \mathrm{Pg} \mathrm{C} \mathrm{yr}^{-1}$ as an input to freshwaters ${ }^{40,41}$. The fourth flux involves photosynthetic $\mathrm{C}$ fixation within inland waters, potentially high on an areal basis ${ }^{16}$. A substantial fraction of this $\mathrm{C}$ is returned to the atmosphere owing to decomposition within inland waters ${ }^{42}$, but a percentage remains for export and burial ${ }^{43,44}$, and priming of terrestrial organic matter decomposition ${ }^{45}$. Thus, although aquatic systems can emit $\mathrm{CO}_{2}$ to the atmosphere, they still can be autotrophic ${ }^{46}$. We estimate with low confidence that $20 \%$ of the organic $C$ buried and exported from inland waters (see below for estimations) is autochthonous $\left(F_{5}\right)$.

Physical erosion of particulate inorganic $\mathrm{C}\left(\sim 0.2 \mathrm{Pg} \mathrm{C} \mathrm{yr}^{-1}\right)$ and of organic $\mathrm{C}$ that is resistant to mineralization $\left(\sim 0.1 \mathrm{Pg} \mathrm{C} \mathrm{yr}^{-1}\right)$ represents another $\mathrm{C}$ source to the aquatic continuum ${ }^{47,48}\left(F_{\mathrm{R}}\right)$. Although the fate of this physically eroded $\mathrm{C}$ is difficult to trace, it is likely to be refractory at the centennial timescale ${ }^{49}$ and is most likely channelled through inland waters and estuaries to the open ocean without significant exchange with the atmosphere. It is thus treated separately in Fig. 1a.

During the transport of $\mathrm{C}$ from soils to the coastal ocean, a fraction of the lateral flux that transits through inland waters is emitted to the atmosphere, mainly as $\mathrm{CO}_{2}\left(F_{7}\right) \cdot \mathrm{CH}_{4}$ is also emitted from lakes and some rivers $\left(F_{6}\right)$, but this flux represents a small fraction of the laterally transported $\mathrm{C}$ flux ${ }^{30}$. Data-driven estimates of the water-to-atmosphere $\mathrm{CO}_{2}$ efflux have been obtained for individual components of the inland freshwater continuum ${ }^{16,17,50}$. This efflux is sustained by $\mathrm{CO}_{2}$ originating from root and soil respiration, aquatic decomposition of dissolved and particulate organic matter, and decomposition of organic $\mathrm{C}$ from sewage, as detailed above. Furthermore, the addition of $\mathrm{C}$ from fringing and riparian wetlands, counted as soil $\mathrm{C}$ input to freshwaters in Fig. 1a, may also contribute significantly to freshwater $\mathrm{CO}_{2}$ outgassing ${ }^{51}$. Approximately 12,000 sampling locations of the inorganic $\mathrm{C}$ cycle are now reported in inland water databases (Fig. 2a). Calculation of $\mathrm{pCO}_{2}$ from alkalinity and $\mathrm{pH}$ indicates that $96 \%$ of inland waters are oversaturated with respect to $\mathrm{CO}_{2}$ relative to its atmospheric concentration, while $82 \%$ have a concentration of at least twice that of the atmosphere (Global River Chemistry Database (GloRiCh), unpublished data; ref. 52).

Numerous measurements of the freshwater $\mathrm{CO}_{2}$ efflux are available for some regions of the globe, such as the Rhine catchment, Scandinavia and the conterminous United States ${ }^{39,42,51-53}$. However, lack of direct $\mathrm{CO}_{2}$ flux measurements, incomplete spatial coverage of $p \mathrm{CO}_{2}$ sampling locations coupled with the difficulty in determining the surface area of inland waters, and scaling the gas-transfer velocity in freshwaters, causes large uncertainties and prevents us from obtaining robust global-scale estimates (Fig. 2a). In particular, many rivers and lakes that contribute a significant fraction to the aquatic $\mathrm{C}$ flux remain poorly surveyed in terms of $p \mathrm{CO}_{2}(\mathrm{GloRiCh}$, unpublished data). These include the rivers of Southeast Asia, tropical Africa and the Ganges and, to a lesser extent, the waters of the Amazon Basin ${ }^{54,55}$, which carry disproportionally high organic 


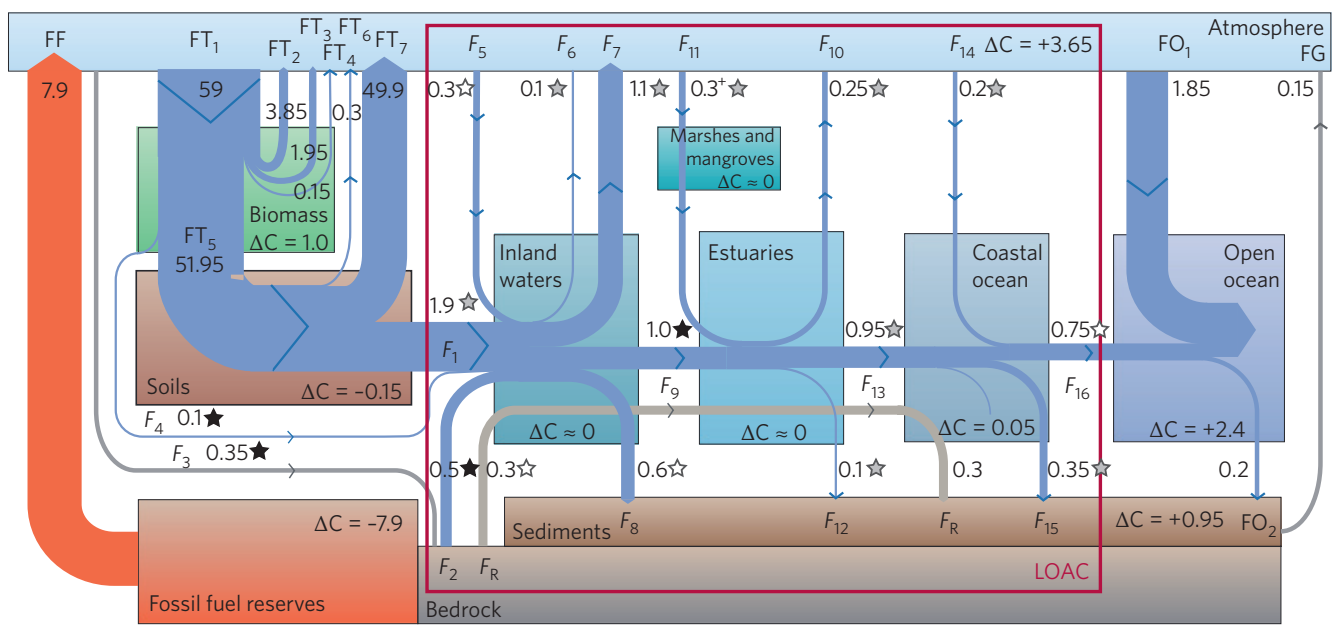

b

Natural

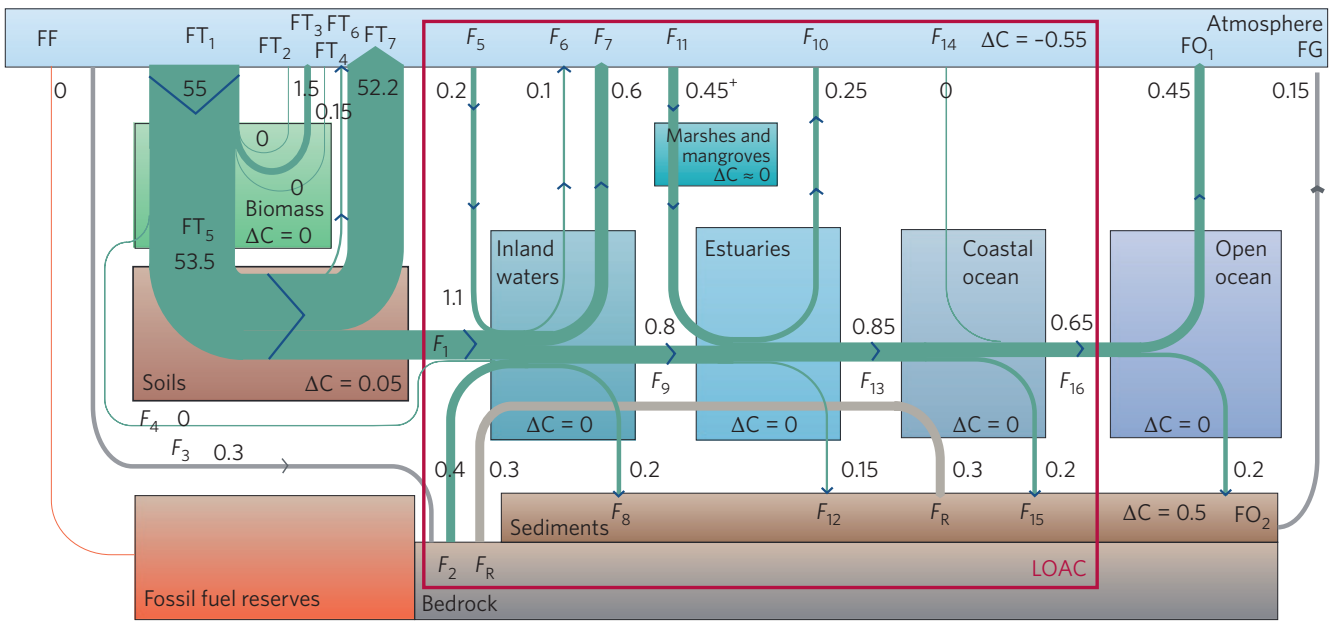

c

Anthropogenic perturbation

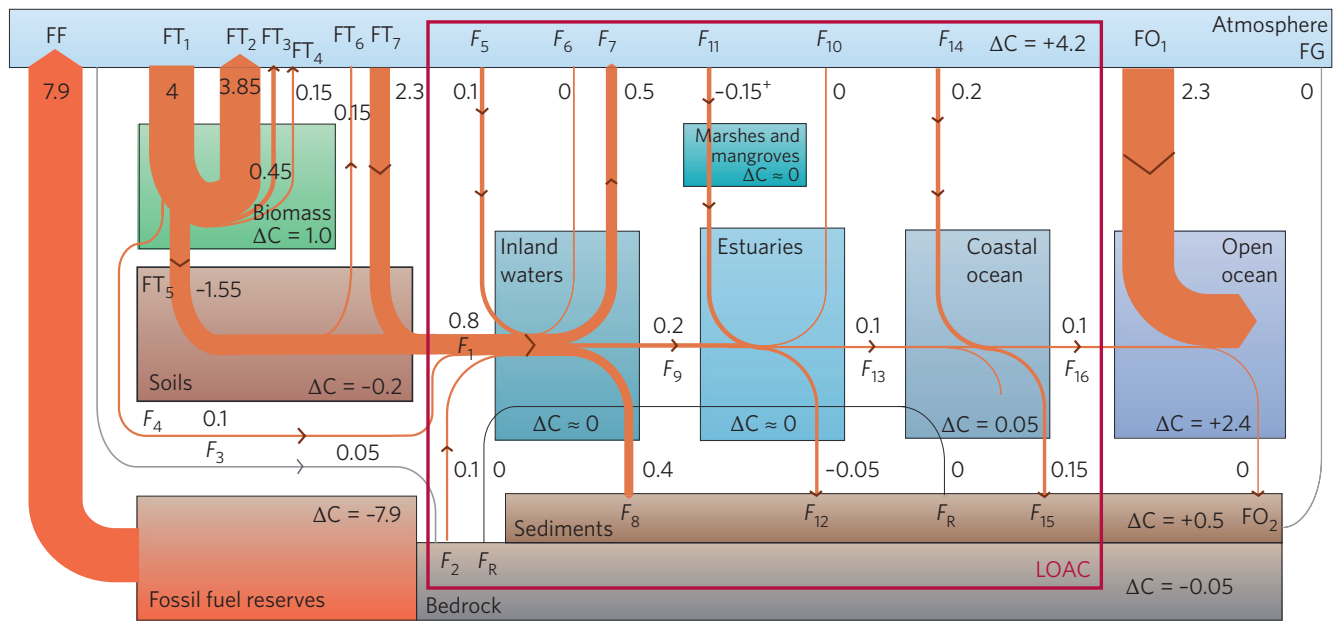

Figure 1 | Global carbon budget and its anthropogenic perturbation. Estimates are shown for a, the present day (2000-2010), b, the natural C cycle ( 1750) and $\mathbf{c}$, the anthropogenic perturbation only. All fluxes are in $\mathrm{Pg} \mathrm{C} \mathrm{yr}^{-1}$, rounded to $\pm 0.05 \mathrm{Pg} C \mathrm{yr}^{-1}$, and refer to total $\mathrm{C}$ fluxes (organic and inorganic C). The numbers associated with the arrows are fluxes between reservoirs. Boxed $\Delta C$ refers to $C$ accumulation within each reservoir. The red box delineates the succession of lateral $\mathrm{C}$ filters along the land-ocean aquatic continuum (LOAC). The + sign indicates that $\mathrm{C}$ sequestration from estuaries and adjacent coastal vegetation are merged in the figure. The stars in panel $\mathbf{a}$ indicate the confidence interval associated to the flux estimates, based on The First State of the Carbon Cycle Report ${ }^{99}$. A black star means 95\% certainty that the actual estimate is within $50 \%$ of the estimate reported; a grey star means $95 \%$ certainty that the actual value is within $100 \%$ of the estimate reported; a white star corresponds to an uncertainty greater than $100 \%$. Flux symbols are defined in Table 1. 


\section{Table 1 | Definition of carbon flux symbols used in Fig. 1.}

\begin{tabular}{|c|c|}
\hline Symbol & Flux name \\
\hline $\mathrm{FF}$ & Fossil-fuel emissions \\
\hline $\mathrm{FT}_{1}$ & Net primary production of terrestrial ecosystems \\
\hline $\mathrm{FT}_{2}$ & Harvest, cattle and biofuels emissions $\left(\mathrm{CO}_{2}\right)$ \\
\hline $\mathrm{FT}_{3}$ & Fire emissions $\left(\mathrm{CO}_{2}\right)$ \\
\hline $\mathrm{FT}_{4}$ & Cattle, landfills and fire emissions $\left(\mathrm{CH}_{4}\right)$ \\
\hline $\mathrm{FT}_{5}$ & Terrestrial biomass to soil C flux \\
\hline $\mathrm{FT}_{6}$ & Rice paddies and wetland emissions $\left(\mathrm{CH}_{4}\right)$ \\
\hline $\mathrm{FT}_{7}$ & Soil heterotrophic respiration $\left(\mathrm{CO}_{2}\right)$ \\
\hline$F_{1}$ & Total soil C input to inland waters \\
\hline$F_{2}$ & Inorganic $\mathrm{C}$ input to inland waters from weathering \\
\hline$F_{3}$ & Atmospheric $\mathrm{CO}_{2}$ uptake by bedrock weathering \\
\hline$F_{4}$ & Organic $\mathrm{C}$ inputs to inland waters (sewage) \\
\hline$F_{5}$ & Photosynthetically fixed $\mathrm{C}$ not respired in inland waters \\
\hline$F_{R}$ & Physical erosion of total recalcitrant $\mathrm{C}$ \\
\hline$F_{6}$ & $\mathrm{CH}_{4}$ emissions from inland waters to the atmosphere \\
\hline$F_{7}$ & $\mathrm{CO}_{2}$ emissions from inland waters to the atmosphere \\
\hline$F_{8}$ & Total C burial in inland water sediments \\
\hline$F_{9}$ & Total lateral C flux from inland waters to estuaries \\
\hline$F_{10}$ & $\mathrm{CO}_{2}$ emissions from estuaries to the atmosphere \\
\hline$F_{11}$ & $\begin{array}{l}\mathrm{CO}_{2} \text { uptake from marsh ecosystems and subsequent organic } \mathrm{C} \\
\text { input to estuaries }\end{array}$ \\
\hline$F_{12}$ & $\begin{array}{l}\text { Total } C \text { burial in estuarine sediments and coastal vegetated } \\
\text { ecosystems }\end{array}$ \\
\hline$F_{13}$ & Total lateral C flux from estuaries to the coastal ocean \\
\hline$F_{14}$ & Atmospheric $\mathrm{CO}_{2}$ uptake by coastal waters \\
\hline$F_{15}$ & Total C burial in coastal ocean sediments \\
\hline$F_{16}$ & Total C export from the coastal to the open ocean \\
\hline $\mathrm{FO}_{1}$ & Air-sea $\mathrm{CO}_{2}$ flux in the open ocean \\
\hline $\mathrm{FO}_{2}$ & Total C burial in open ocean sediments \\
\hline FG & $\begin{array}{l}\text { Geological fluxes (volcanism, metamorphism and oxidation of } \\
\text { fossil organic C) }\end{array}$ \\
\hline
\end{tabular}

carbon loads owing to their combination of high terrestrial productivity, high decomposition rates and high uniform precipitation rates (Fig. 2a). The scarcity of direct $p \mathrm{CO}_{2}$ measurements and lack of knowledge on regional surface area and gas-transfer velocity explain the large uncertainty in the $\mathrm{CO}_{2}$ outgassing from freshwaters ${ }^{8,16,26,51}$, with a range of $0.6-1.25 \mathrm{Pg} \mathrm{C} \mathrm{yr}^{-1}$. The values at the higher end of the spectrum also include the contribution of streams and small lakes, which are typically not considered in flux estimates ${ }^{26}$. We estimate a most likely value of the $\mathrm{CO}_{2}$ outgassing flux of $1.1 \mathrm{Pg} \mathrm{C} \mathrm{yr}^{-1}\left(F_{7}\right)$ with a medium-to-low confidence.

The burial rate in freshwater sediments has been estimated to be between $\sim 0.2$ and $1.6 \mathrm{Pg} \mathrm{C} \mathrm{yr}^{-1}$. The lower estimate refers to lakes, ponds and reservoirs only ${ }^{16,26}\left(0.2-0.6 \mathrm{Pg} \mathrm{C} \mathrm{yr}^{-1}\right)$, whereas the upper one also includes sedimentation in floodplains $s^{6,56,57}(0.5-$

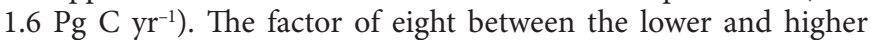
bound estimates of this burial flux highlights the limited observational data available to constrain this term at the global scale. Within this large uncertainty, we adopt with a low confidence a value of $0.6 \mathrm{Pg} \mathrm{C} \mathrm{yr}^{-1}$ for the $\mathrm{C}$ burial in inland water sediments $\left(F_{8}\right)$. Part of this burial is carbon transported, by erosion processes, from soils to lake sediments and floodplains.

From the mass balance of the $\mathrm{C}$ input from soils to fresh waters minus $\mathrm{CO}_{2}$ outgassing and $\mathrm{C}$ burial fluxes in inland waters adopted here, the output represents a lateral $\mathrm{C}$ flux transported downstream into estuarine systems $\left(F_{9}\right)$ of $1.0 \mathrm{Pg} \mathrm{C} \mathrm{yr}^{-1}$. Thus our estimate is close to values based on compilation of field data ${ }^{47,58}$ and the results of the Global Nutrient Export from Watersheds model of carbon and water flows ${ }^{59}$, although higher values have also been suggested ${ }^{8}$. A flux of particulate and dissolved organic $\mathrm{C}$, each equivalent to about $0.2 \mathrm{Pg} \mathrm{C} \mathrm{yr}^{-1}$, and a flux of dissolved inorganic $\mathrm{C}$ of about $0.4 \mathrm{Pg} \mathrm{C} \mathrm{yr}^{-1}$ is the conventional partitioning among the different $\mathrm{C}$ pools ${ }^{47,58,60,61}$. If we take into account the uncertainty for each of the individual inland water fluxes (weathering, outgassing, burial and export), the balance also indicates that the soil-derived $\mathrm{C}$ flux

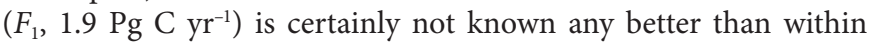
$\sim \pm 1.0 \mathrm{Pg} \mathrm{C} \mathrm{yr}^{-1}$.

Estuaries. In our analysis, estuaries (total area of $1.1 \times 10^{6} \mathrm{~km}^{2}$ ) correspond to the boundary between inland aquatic systems and the coastal ocean, represented mainly by the shelves of the world's oceans ${ }^{62}$. Recent syntheses of observational data indicate that estuaries emit $\mathrm{CO}_{2}$ to the atmosphere ${ }^{27,63}$, within the range of $0.25 \pm 0.25 \mathrm{Pg} \mathrm{C} \mathrm{yr}^{-1}\left(F_{10}\right)$. Field measurements suggest that about $10 \%$ of the $\mathrm{CO}_{2}$ outgassing from estuaries is sustained by the input from upstream freshwaters $\left(F_{9}\right)$ and $90 \%$ by local net heterotrophy ${ }^{64}$, with a significant fraction of the required organic $\mathrm{C}$ coming from adjacent marsh ecosystems $\left(F_{11}\right)$. Although coastal vegetated environments (salt marshes, mangroves, seagrasses, macroalgae and coral reefs) may export as much as $0.77-3.18 \mathrm{Pg} \mathrm{C} \mathrm{yr}^{-1}$ to the coastal ocean ${ }^{65}$, we use here a more conservative estimate of $\sim 0.3 \pm 0.1 \mathrm{Pg} \mathrm{C} \mathrm{yr}^{-1}$ for the common estuarine vegetation of mangroves and salt marshes, which is based on an upscaling of a detailed regional budget for the southeastern United States ${ }^{63}$. Furthermore, to our knowledge, no global estimates exist for $\mathrm{C}$ burial in all estuarine sediments, but a long-term burial in mangroves and salt marshes of $0.1 \pm 0.05 \mathrm{Pg} \mathrm{C} \mathrm{yr}^{-1}$ has been proposed ${ }^{18,66}\left(F_{12}\right)$. If we combine our upstream river and coastal vegetation inputs with our average estuarine $\mathrm{CO}_{2}$ outgassing estimate to the atmosphere and the first-order estimate for burial of $\mathrm{C}$ in estuarine sediments and vegetated ecosystems $\left(F_{12}\right)$, we obtain a $C$ delivery from estuaries to the coastal ocean of $0.95 \mathrm{Pg} \mathrm{C} \mathrm{yr}^{-1}\left(F_{13}\right)$. This estimate amounts to about one-third of the initial $\mathrm{C}$ flux released from soils, rocks and sewage as input to inland freshwater systems.

Coastal ocean and beyond. Materials leaving estuaries transit into the coastal ocean and beyond to the open ocean. Recent syntheses of the air-sea $\mathrm{CO}_{2}$ fluxes in coastal waters (total area of $31 \times 10^{6}$ $\left.\mathrm{km}^{2}\right)^{62}$ suggest that at present between 0.22 and $0.45 \mathrm{Pg} \mathrm{C} \mathrm{yr}^{-1}$ are taken up by the coastal ocean ${ }^{67,68}$. We choose here a lower estimate of $0.2 \mathrm{Pg} \mathrm{C} \mathrm{yr}^{-1}$ for the coastal ocean sink of $\mathrm{CO}_{2}$, based on a recent analysis for the global ocean ${ }^{69}\left(F_{14}\right)$. This value relies on the observation that, outside the nearshore environments, the net $\mathrm{CO}_{2}$ fluxes in the coastal regions are of similar strengths and directions to those in the adjacent ocean regions, that is, that low-latitude coastal regions tend to be sources of $\mathrm{CO}_{2}$ to the atmosphere, whereas highlatitude regions tend to be sinks $s^{67,68}$. This allows the extrapolation of the open-ocean $\mathrm{CO}_{2}$ exchange values towards the coasts. Although this extrapolation is an oversimplification, the most recent estimate

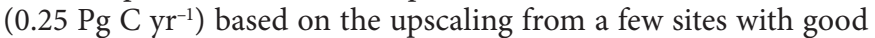
observational coverage suggests a similar value ${ }^{63}$. Nevertheless, it is important to recognize that the limited spatial coverage of $p \mathrm{CO}_{2}$ data in the coastal ocean (Fig. 2b) and its heterogeneous nature confine the confidence to low-to-medium. Furthermore, the influence of terrestrial $\mathrm{C}$ input on air-sea $\mathrm{CO}_{2}$ fluxes extends considerably beyond the limit of the shelf in the discharge plumes of large tropical rivers, such as the Amazon ${ }^{63,70}$. These plumes should be considered as an integral part of the land-ocean continuum.

Coastal ocean sediments may sequester between 0.2 and

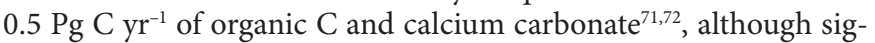
nificantly higher values have been reported ${ }^{73}\left(F_{15}\right)$. We choose here a central estimate of $0.35 \mathrm{Pg} \mathrm{C} \mathrm{yr}^{-1}$, of which a sediment $\mathrm{C}$ burial of 

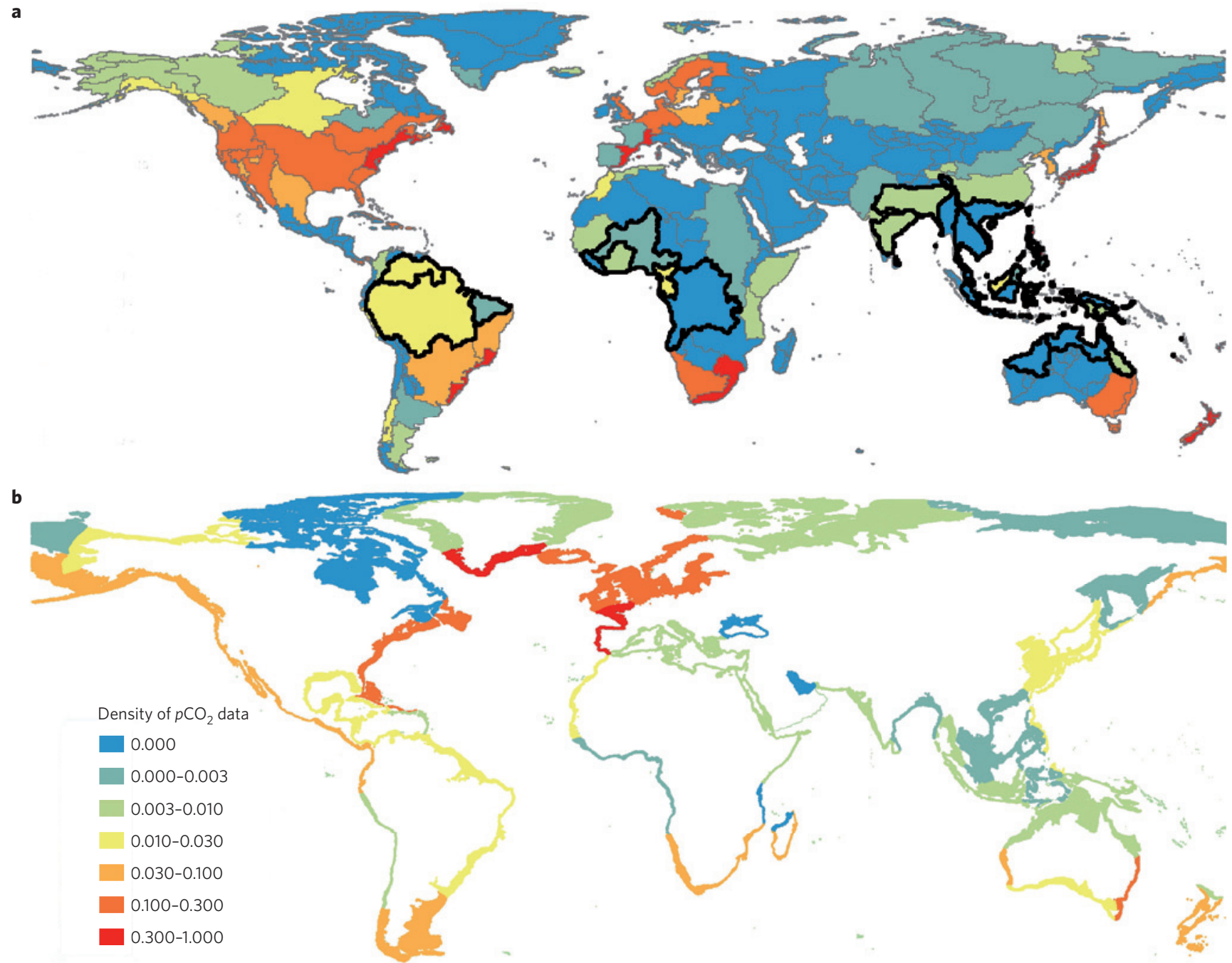

Figure 2 | Density of $p \mathrm{CO}_{2}$ data for the continuum of land-ocean aquatic systems. $p \mathrm{CO}_{2}$ values are shown for a, inland waters (Global River Chemistry database) and $\mathbf{b}$, continental shelf seas (Surface Ocean Carbon Atlas database). The index reports the data density with respect to spatial coverage (using a $0.5^{\circ}$ resolution) and seasonality. Inland waters are represented by 150 meta-watersheds ${ }^{100}$, and coastal waters by 45 continental shelf segments ${ }^{62}$. The surface area of inland waters within each segment is available at www.biogeomod.net/geomap. The index is calculated following the equation $I=\left(\sum_{i=1}^{n} c_{i}\right) /(n \times 12)$ where $l$ is the index itself, $n$ is the number of $0.5^{\circ}$ grid cells and $c_{i}$ is the count corresponding to the number of months for which at least one $\mathrm{pCO}_{2}$ value exists within the grid cell $i$. A value of 0 indicates a complete absence of data and a value of 1 indicates the presence of at least one $\mathrm{pCO}_{2}$ value every month in each of the grid cells of the considered area. The black lines in a represent the limits of hotspot areas for $\mathrm{CO}_{2}$ evasion to the atmosphere. All the inland water $\mathrm{pCO}_{2}$ values were calculated from alkalinity, $\mathrm{pH}$ and water temperature.

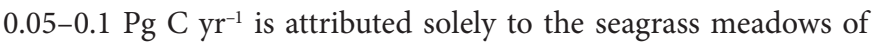
shallow coastal seas ${ }^{18}$. In addition, the most probable repository for much of the recalcitrant terrestrial $\mathrm{C}$ related to physical weathering $\left(F_{\mathrm{R}}\right)$ is likely to be in coastal sediment $\mathrm{C}$ pools ${ }^{74,75}$. Furthermore, the net pumping of anthropogenic $\mathrm{CO}_{2}$ from the atmosphere into coastal waters may increase the dissolved inorganic carbon storage in the water column ${ }^{76}$, by about $0.05 \mathrm{Pg} \mathrm{C} \mathrm{yr}^{-1}$. Because of data paucity, a direct global estimate of lateral $\mathrm{C}$ fluxes at the boundary between the coastal and open ocean, delineated by the shelf break $^{62}$, is not at present achievable solely through observational means ${ }^{12,70,77}$. Thus, based on mass-balance calculations using the above flux estimates, we propose with a low confidence that the net inorganic and organic $\mathrm{C}$ export from the coastal ocean to the open ocean is $\sim 0.75 \mathrm{Pg} \mathrm{C} \mathrm{yr}^{-1}\left(F_{16}\right)$ as shown in Fig. 1a.

\section{Anthropogenic perturbation of lateral carbon fluxes}

As with the contemporary lateral C fluxes, we now trace sequentially the route of the perturbed $\mathrm{C}$ fluxes through the global system of inland waters to estuaries to coastal waters and beyond.

Inland waters. Reconstructions of the historical evolution (preindustrial, around the year 1750, to present) of the global aquatic $\mathrm{C}$ cycle and its fluxes have so far relied primarily on globally averaged box models ${ }^{7,74}$. Increasing concentrations of atmospheric $\mathrm{CO}_{2}$, land-use changes, nitrogen and phosphorus fertilizer application, $\mathrm{C}$, nitrogen and phosphorus sewage discharge and global surface temperature change drive these highly parameterized models. Model simulations suggest that the transport of riverine $\mathrm{C}\left(F_{9}\right)$ has increased by about $20 \%$ since 1750 , from $\sim 0.75 \mathrm{Pg} \mathrm{C} \mathrm{yr}^{-1}$ in 1750 to 0.9-0.95 $\mathrm{Pg} \mathrm{C} \mathrm{yr}^{-1}$ at present. The existence of such an enhanced riverine delivery of $\mathrm{C}$ is supported by the available literature data $\mathrm{a}^{3,8,47,78}$, and has been attributed to deforestation and more intensive cultivation practices that have increased soil degradation and erosion. This leads to an increase in the export of organic and inorganic $\mathrm{C}$ 
to aquatic systems ${ }^{9}$. For example, erosion of particulate organic $\mathrm{C}$ in

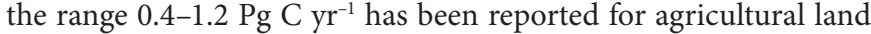
alone $e^{6,14,79}$. However, only a percentage of this flux represents a lateral transfer of anthropogenic $\mathrm{CO}_{2}$ fixed by photosynthesis ${ }^{6,56,79,80}$.

Although budgets have been established for present-day conditions ${ }^{16,26}$, there is no observationally based estimate of the preindustrial $\mathrm{C}$ flux from soils to inland waters, nor of the associated $\mathrm{CO}_{2}$ outgassing and $\mathrm{C}$ burial fluxes in freshwater systems in preindustrial times. Furthermore, we are not aware of any spatially explicit model simulation of the $\mathrm{CO}_{2}$ outgassing and $\mathrm{C}$ burial fluxes in inland aquatic systems during the industrial period at the global scale. The potential anthropogenic effects on $\mathrm{C}$ cycling in various inland aquatic systems have been reviewed ${ }^{16}$, but a quantitative estimate of the anthropogenic perturbation remains to be assessed. The bulk fluxes are nevertheless large enough that even a small change would alter the global $\mathrm{C}$ budget of anthropogenic $\mathrm{CO}_{2}$. For example, it is highly likely that damming and freshwater withdrawal have impacted the $\mathrm{CO}_{2}$ outgassing fluxes and organic carbon burial rates since pre-industrial time through their effect on surface area and residence time of inland waters ${ }^{2,6,8}$. In particular, the evolution in agricultural practices and the construction of humanmade impoundments during the past century have most likely led to enhanced $\mathrm{CO}_{2}$ outgassing. A $\mathrm{CO}_{2}$ evasion of $0.3 \mathrm{Pg} \mathrm{C} \mathrm{yr}^{-1}$ for human-made reservoirs alone has been reported ${ }^{16}$. Furthermore, a $\mathrm{C}$ burial flux in the sediments of reservoirs and small agricultural ponds of $0.35 \mathrm{Pg} \mathrm{C} \mathrm{yr}^{-1}$ has also been estimated ${ }^{2,6,8,16,26,56}$, with $\mathrm{C}$ probably from terrestrial and autochthonous sources.

To estimate the extent to which other inland water environments such as lakes, streams and rivers have been perturbed by human activities, we assume that $\mathrm{CO}_{2}$ outgassing and $\mathrm{C}$ burial fluxes in these systems linearly scale with the estimated increase $(\sim 20 \%)$ in soil-derived $C$ exported from rivers to estuaries $\left(F_{9}\right)$ and the coastal zone $^{81}$ (see also above). This leads to a perturbation of $\sim 0.1 \mathrm{Pg} \mathrm{C} \mathrm{yr}^{-1}$ for the $\mathrm{CO}_{2}$ outgassing flux and $\sim 0.05 \mathrm{Pg} \mathrm{C} \mathrm{yr}^{-1}$ for the $\mathrm{C}$ burial flux. The linear scaling assumption implies that $\mathrm{CO}_{2}$ outgassing and the $\mathrm{C}$ sedimentation rate are first order processes with respect to the additional $\mathrm{C}$ concentration derived from enhanced exports from soil in the freshwater aquatic systems. This assumption is probably reasonable for the air-water flux, but the change in $\mathrm{C}$ burial flux is almost surely more complex ${ }^{8}$.

Sewage inputs to upstream rivers $\left(F_{4}\right)$ are inferred to add another

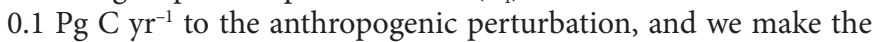
assumption that this labile organic $\mathrm{C}$ is entirely outgassed within inland waters. Combining all contributions, the budget analysis gives $\mathrm{CO}_{2}$ outgassing $\left(F_{7}\right)$ and $\mathrm{C}$ burial $\left(F_{8}\right)$ fluxes under preindustrial conditions of 0.6 and $0.2 \mathrm{Pg} \mathrm{C} \mathrm{yr}^{-1}$, respectively (Fig. 1b). The remaining extra outgassing $\left(0.5 \mathrm{Pg} \mathrm{C} \mathrm{yr}^{-1}\right)$ and extra burial

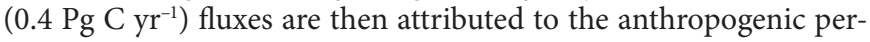
turbation (Fig. 1c). Furthermore, increased chemical weathering of continental surfaces caused by human-induced climate change and increased $\mathrm{CO}_{2}$ levels contributes to the enhanced riverine export flux of $\mathrm{C}$ derived from rock weathering ${ }^{82,83}\left(F_{2}\right)$. The anthropogenic perturbation could possibly reach $0.1 \mathrm{Pg} \mathrm{C} \mathrm{yr}^{-1}$, mainly through enhanced dissolution of carbonate rocks ${ }^{83}$. The impact of land-use change on weathering rates may have started 3,000 years ago $^{84}$ but its effect on atmospheric $\mathrm{CO}_{2}$ is difficult to assess ${ }^{85,86}$. For example, $\mathrm{C}$ mobilized from the practice of agricultural liming is a source of enhanced land-use $\mathrm{C}$ fluxes ${ }^{85}$ and could result in a sink of $\sim 0.05 \mathrm{Pg} \mathrm{C} \mathrm{yr}^{-1}$.

Summing up, the total present-day flux from soils, bedrock and sewage to aquatic systems of $2.5 \mathrm{Pg} \mathrm{C} \mathrm{yr}^{-1}$ shown in Fig. 1a can be decomposed as the sum of a natural flux of $\sim 1.5 \mathrm{Pg} \mathrm{C} \mathrm{yr}^{-1}$ (Fig. 1b) and an anthropogenic perturbation flux of $\sim 1.0 \mathrm{Pg} \mathrm{C} \mathrm{yr}^{-1}$ (Fig. 1c) - a value that is similar to a previously published estimate ${ }^{8}$. Roughly $50 \%$ of this anthropogenic perturbation $\left(0.5 \mathrm{Pg} \mathrm{C} \mathrm{yr}^{-1}\right)$ is respired back to the atmosphere in freshwater systems $\left(F_{7}\right)$, while the remainder contributes to enhanced $\mathrm{C}$ burial $\left(F_{8}\right)$ and export to estuaries $\left(F_{9}\right)$ and, perhaps, to the coastal ocean $\left(F_{13}\right.$, Fig.1c).

Estuaries. The perturbation of historical drainage and humancaused conversion of salt marshes and mangroves, as well as the channelization of estuarine conduits, have modified the estuarine $\mathrm{C}$ balance. For instance, the total loss of $\mathrm{C}$ from these intertidal $\mathrm{C}$ pools could be as high as $25-50 \%$ over the past century, mainly because of land-use change ${ }^{18}$. Assuming that the reduction in the $\mathrm{C}$ flux from marshes and mangrove ecosystems to estuaries $\left(F_{11}\right)$ is proportional to the reduction in the surface area of these ecosystems, we estimate that the pre-industrial flux of $\mathrm{C}$ transported from coastal vegetation to estuaries must have been about $0.15 \mathrm{Pg} \mathrm{C} \mathrm{yr}^{-1}$ larger than that of the present-day value of $0.30 \mathrm{Pg} \mathrm{C} \mathrm{yr}^{-1}$. We predict that $\mathrm{C}$ burial in estuarine sediments has been reduced from pre-industrial times to the present by the same relative factor, amounting to an anthropogenic reduction of $0.05 \mathrm{Pg} \mathrm{C} \mathrm{yr}^{-1}$ of the estuarine sediment $\mathrm{C}$ burial flux $\left(F_{12}\right)$ in Fig. 1b. In the absence of independent evidence, we assume that the air-sea estuarine flux of $\mathrm{CO}_{2}$ has remained constant since pre-industrial times $\left(F_{10}\right.$, Fig. $\left.1 c\right)$. With the constraints mentioned above, closing the mass balance of the pre-industrial and present-day estuarine $\mathrm{C}$ budgets requires that the $\mathrm{C}$ export to the coastal ocean $\left(F_{13}\right)$ has increased by $\sim 0.1 \mathrm{Pg} \mathrm{C} \mathrm{yr}^{-1}$ since 1750 , from

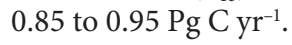

Coastal ocean and beyond. Lacking sufficient observational evidence, we have to rely on process-based arguments and models to separate present-day $C$ fluxes for the coastal ocean into pre-industrial and anthropogenic components. Perhaps the best constrained flux component is the uptake of anthropogenic $\mathrm{CO}_{2}$ across the airsea interface, which has been estimated to about $0.2 \mathrm{Pg} \mathrm{C} \mathrm{yr}^{-1}$, on the basis that this uptake has the same flux density as that of the mean ocean $^{69}$, namely about $6 \mathrm{~g} \mathrm{C} \mathrm{m}^{-2} \mathrm{yr}^{-1}$. This assumption is warranted as the oceanic uptake flux of anthropogenic $\mathrm{CO}_{2}$ is to first order controlled by the surface area. Much less certain is the degree to which the enhanced nutrient and $\mathrm{C}$ inputs to the coastal ocean could have modified the air-sea $\mathrm{CO}_{2}$ balance. Box model simulations for the global coastal ocean suggested that the enhanced supply of nutrients from land may have increased coastal productivity and $\mathrm{C}$ burial in coastal sediments ${ }^{87}$, from about $0.2 \mathrm{Pg} \mathrm{C} \mathrm{yr}^{-1}$ to $0.35 \mathrm{Pg} \mathrm{C} \mathrm{yr}^{-1}$, as well as contributing to a substantial increase in the air-to-sea $\mathrm{CO}_{2}$ flux $^{12,74}$, by up to $0.2-0.4 \mathrm{Pg} \mathrm{C} \mathrm{yr}^{-1}$. However, the efficiency by which the additional nutrient supply delivered to the coastal ocean is actually reducing $p \mathrm{CO}_{2}$ and enhancing the net uptake of $\mathrm{CO}_{2}$ is globally uncertain. For example, on continental shelves, the enhanced supply of nitrogen $\left(<50 \mathrm{Tg} \mathrm{N} \mathrm{yr}^{-1}\right)^{88,89}$ may stimulate a maximal additional growth of about $0.3 \mathrm{Pg} \mathrm{C} \mathrm{yr}^{-1}$, of which only a portion is exported to depth, and of which less than $50 \%$ is replaced by uptake of $\mathrm{CO}_{2}$ from the atmosphere ${ }^{90}$. We estimate that coastal eutrophication has caused an increase in the air-to-sea $\mathrm{CO}_{2}$ flux no larger than $\sim 0.1 \mathrm{Pg} \mathrm{C} \mathrm{yr}^{-1}$. The response of the highly heterogeneous, very shallow coastal ocean, including reefs, banks and bays $\left(<50 \mathrm{~m}, 12 \times 10^{6}\right.$ $\left.\mathrm{km}^{2}\right)^{62}$, remains largely unknown. However, it is in this region that the nutrient impact on biological productivity, organic $\mathrm{C}$ burial and area-specific $\mathrm{CO}_{2}$ fluxes is expected to be the highest. Therefore, the anthropogenic air-coastal water $\mathrm{CO}_{2}$ flux is only known with low confidence. We estimate a conservative value of $0.2 \mathrm{Pg} \mathrm{C} \mathrm{yr}^{-1}$ for this anthropogenic flux $\left(F_{14}\right)$, which is significantly lower than the value of $0.5 \mathrm{Pg} \mathrm{C} \mathrm{yr}^{-1}$ suggested in recent syntheses ${ }^{70}$.

The fate of the additional $C$ received from the estuaries $\left(F_{13}\right)$ is unclear. Some of this $\mathrm{C}$ is probably sequestered in coastal sediments, together with some of the additional organic $\mathrm{C}$ produced in response to the nutrient input, amounting to a flux potentially as large as $0.1-0.15 \mathrm{Pg} \mathrm{C} \mathrm{yr}^{-1}\left(F_{15}\right)$. The remainder is exported to the open ocean, together with some of the anthropogenic $\mathrm{CO}_{2}$ taken up from the atmosphere, amounting to a flux of approximately 


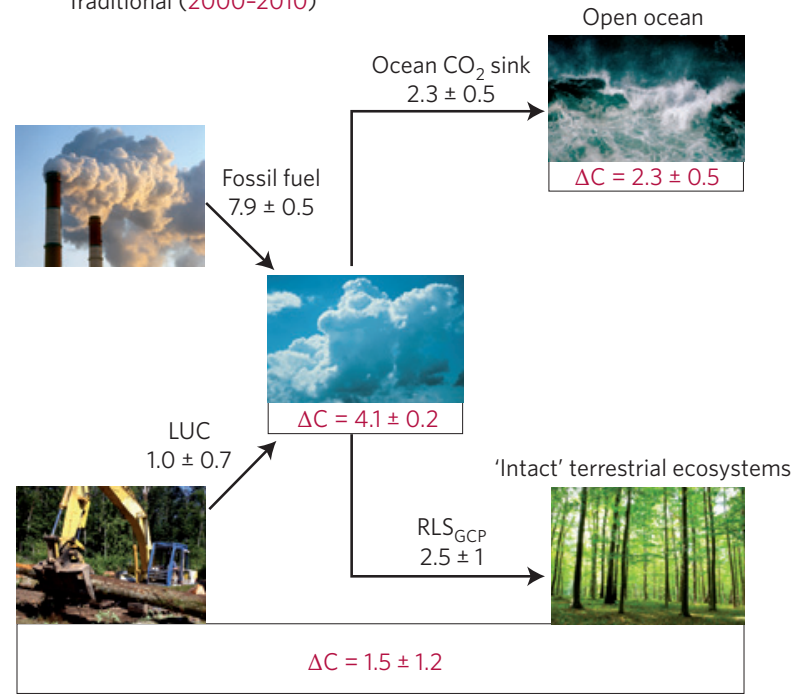

'LUC' affected ecosystems b Boundless (2000-2010)

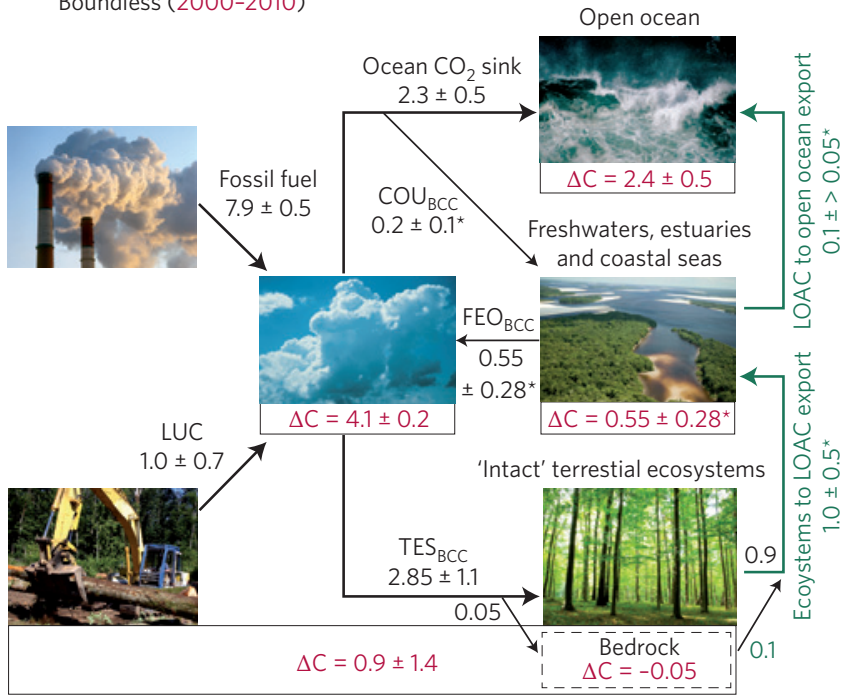

'LUC' affected ecosystems

Figure 3 | Global budget of anthropogenic $\mathrm{CO}_{2}$. Only the perturbation fluxes are shown in this figure (see Fig. 1 for natural fluxes). Units are Pg C yr $r^{-1}$. a, Global budget from the Global Carbon Project (GCP), in which the sum of fossil-fuel and land-use change (LUC) net annual emissions to the atmosphere is partitioned between the ocean sink of $\mathrm{CO}_{2}$, the observed atmospheric annual $\mathrm{CO}_{2}$ increase and the atmosphere-to-land $\mathrm{CO}_{2}$ flux in ecosystems not affected by LUC. The latter is deduced as a difference from all other terms and is called the residual land sink of $\mathrm{CO}_{2}\left(\mathrm{RLS}_{\mathrm{GCP}}\right)$. The land storage change is calculated as $\mathrm{RLS}_{\mathrm{GCP}}$ - LUC emissions. Reported uncertainties correspond to $1 \sigma$ confidence interval of Gaussian error distributions. b. Same budget in presence of 'boundless'

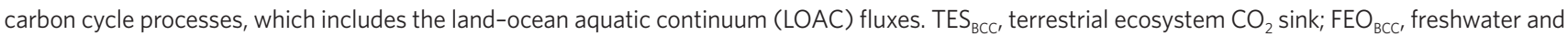
estuarine aquatic ecosystem outgassing; $\mathrm{CO}_{\mathrm{BC}}$, coastal ocean uptake. The processes represented on the right-hand side of the figure move carbon laterally from land ecosystems to the oceans, resulting in (1) a net terrestrial ecosystem carbon storage increase smaller than the residual terrestrial sink of $\mathrm{CO}_{2}$ ( 2 ) burial of displaced carbon downstream into freshwater and coastal sediments, (3) outgassing of $\mathrm{CO}_{2}$ to the atmosphere en route between land and the coastal ocean, and (4) a net open ocean carbon storage increase larger than the atmosphere to ocean $\mathrm{CO}_{2}$ flux. For clarity, reservoirs to atmosphere fluxes of $\mathrm{CO}_{2}$ are in black, lateral fluxes of carbon displaced at the surface are in green, and changes in (anthropogenic) carbon storage of each reservoir are given in red. In the figure, $\mathrm{TES}_{\mathrm{BCC}}=\mathrm{RLS}_{\mathrm{GCP}}+\mathrm{FEO}_{\mathrm{BCC}}-\mathrm{COU}_{\mathrm{BCC}}$. The 'net atmosphere-terrestrial ecosystems $\mathrm{CO}_{2}$ sink' is equal to TES $\mathrm{BCC}_{-}-\mathrm{LUC}$. The 'net anthropogenic $\mathrm{CO}_{2}$ outgassing' for the freshwater-estuary-coastal zone continuum is $\mathrm{FEO}_{\mathrm{BCC}}-\mathrm{COU}_{\mathrm{BCC}}$. Uncertainties on fluxes are from the GCP, except for the LOAC fluxes (identified by an asterisk), where indicative estimates are given based on the categorization proposed in The First State of the Carbon Cycle Report ${ }^{99}$ and for $T_{E S}$ BCC (see below). The same applies for the uncertainty on the LOAC carbon storage change. The uncertainty on TES is calculated from the atmospheric mass balance, assuming quadratic errors propagation, and a similar approach is used for the uncertainty on carbon storage $(\Delta C)$ for the terrestrial ecosystems and open ocean, based on their respective mass balance. The uncertainty associated to each LOAC flux was estimated using the categories proposed in The First State of the Carbon Cycle Report. These categories have then been converted to uncertainty values assuming that they follow a Gaussian error distribution. $1 \sigma \approx \mu / 4: 95 \%$ certain that the estimate is within $50 \%$ of the proposed value. $1 \sigma \approx \mu / 2: 95 \%$ certain that the estimate is within $100 \%$ of the proposed value. $1 \sigma$ $>\mu / 2$ : uncertainty greater than $100 \% . \mu=$ mean value.

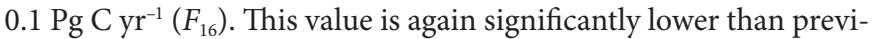
ous estimates $^{70}$, highlighting that our confidence in these numbers is very low.

In summary, although accurate quantification remains challenging, one can firmly conclude that during the industrial era, the laterally transported $\mathrm{C}$ fluxes and the vertically exchanged atmospheric $\mathrm{CO}_{2}$ fluxes relevant to the land-ocean aquatic continuum have been significantly altered by human activities, the main driver being landuse changes. Our analysis suggests that out of the $\sim 1.1 \mathrm{Pg} \mathrm{C} \mathrm{yr}^{-1}$ of extra anthropogenic $\mathrm{C}$ delivered to the continuum of land-ocean aquatic systems (0.8 $\mathrm{Pg} \mathrm{C} \mathrm{yr}^{-1}$ from soils, $0.1 \mathrm{Pg} \mathrm{C} \mathrm{yr}^{-1}$ from weathering, $0.1 \mathrm{Pg} \mathrm{C} \mathrm{yr}^{-1}$ from sewage, $0.1 \mathrm{Pg} \mathrm{C} \mathrm{yr}^{-1}$ from enhanced $\mathrm{C}$ fixation in inland waters), at present approximately $50 \%$ is sequestered in inland water, estuarine and coastal sediments, $<20 \%$ is exported to the open ocean and the remaining $>30 \%$ is emitted to the atmosphere as $\mathrm{CO}_{2}$. $\mathrm{CO}_{2}$ fluxes along the land-ocean continuum may not only be altered directly by increased anthropogenic $\mathrm{C}$ export from soil and subsequent respiration, but also indirectly by enhanced decomposition of autochthonous organic materials triggered by priming. This indirect process may be a quantitatively relevant contribution to the estimated fluxes and the observed net heterotrophy of many systems, but cannot yet be quantified ${ }^{45,91}$. The uncertainties associated with our breakdown are large and represent a fundamental obstacle for global $\mathrm{C}$ cycle assessments and a fertile avenue for future research (see also Fig. 3). Future work that succeeds in narrowing down the uncertainties on the anthropogenic perturbations may overrule our conclusions on the quantitative value of each flux in the analysis, but is unlikely to affect our conclusion that the anthropogenic perturbation to the aquatic continuum $\mathrm{C}$ fluxes is important for the global carbon budget.

\section{Implications for the global carbon budget}

Quantitative assessment of the C fluxes through the land-ocean aquatic continuum in a so-called boundless $\mathrm{C}$ cycle analysis has important implications for how terrestrial $\mathrm{C}$ fluxes ought to be evaluated and how the sinks of anthropogenic $\mathrm{CO}_{2}$ over land and ocean need to be attributed. This assessment has implications for terrestrial ecosystem $\mathrm{C}$ cycling, global terrestrial and ocean $\mathrm{C}$ models, atmospheric inversions, ocean $\mathrm{C}$ inventories and the global anthropogenic $\mathrm{CO}_{2}$ budget. The land $\mathrm{C}$ cycle (see Supplementary Note for further details) is driven by the $\mathrm{C}$ input to ecosystems due to net

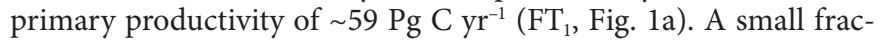
tion of net primary productivity is used by ecosystems to increase C stocks, as evidenced by the net growth of many forests ${ }^{92}$. Humans and fires consume another fraction $\left(\mathrm{FT}_{2}\right.$ and $\left.\mathrm{FT}_{3}\right)$, and litter production $\left(\mathrm{FT}_{5}\right)$ is thus actually lower now than what it was for the natural 
cycle. After some time of residency in ecosystems, most of the $\mathrm{C}$ is returned to the atmosphere as $\mathrm{CO}_{2}$ by heterotrophic respiration $\left(\mathrm{FT}_{7}\right)$, while a small fraction is channelled to freshwaters.

In the majority of global terrestrial ecosystem model formulations, the lateral $\mathrm{C}$ fluxes from soils to freshwaters are not represented, and modellers assume one-dimensional closure of $\mathrm{C}$ between terrestrial ecosystem pools and the atmosphere. Consequently, soil heterotrophic respiration is overestimated in these models relative to observations. Similarly, global ocean biogeochemistry models use prescribed lateral input of $\mathrm{C}$ (or nutrients) from land as an input for the open ocean. At present, their coarse resolution does not resolve the coastal ocean well, and their simple, globally tuned formulations of ecosystem and biogeochemical processes may not be able to capture fully the complexity of the impacts of the enhanced terrestrial inputs of $\mathrm{C}$ and nutrients on the coastal ocean.

Atmospheric $\mathrm{CO}_{2}$ inversion models estimate regional scale net land-atmosphere $\mathrm{CO}_{2}$ fluxes from $\mathrm{CO}_{2}$ concentration gradients measured by surface network stations. Thus, the lateral transport of $\mathrm{C}$ at the surface is not a process generally considered in inversion modelling, which only detects vertical $\mathrm{CO}_{2}$ fluxes. Inversion estimates of land-atmosphere $\mathrm{CO}_{2}$ fluxes do include $\mathrm{CO}_{2}$ exchange with inland waters and estuaries in their regional output. However, the spatial resolution of inversion $\mathrm{CO}_{2}$ exchange estimates is too coarse, and the atmospheric sampling too sparse to separate $\mathrm{CO}_{2}$ fluxes from inland waters from those exchanged by terrestrial ecosystems. The same caveat applies for atmospheric inversions of the air-sea $\mathrm{CO}_{2}$ fluxes. These inversion approaches evaluate the net flux across the air-sea interface, which includes the effect of the lateral and vertical $\mathrm{C}$ exchanges along the aquatic continuum, in particular the net outgassing of the riverine carbon ${ }^{93}$.

Changes in the open-ocean $\mathrm{C}$ inventory over the historical period have been used to infer the cumulated oceanic C sink. Most recently, a global oceanic storage of anthropogenic C of $155 \pm 30 \mathrm{Pg} \mathrm{C}$ for the period from 1800 to 2010 has been estimated ${ }^{94}$. This storage includes 'only' that part of the $\mathrm{C}$ that has been taken up through the air-sea interface in response to the increase in atmospheric $\mathrm{CO}_{2}$, that is, the anthropogenic $\mathrm{CO}_{2}$. Not included in this oceanic net $\mathrm{C}$ sink estimate is any additional air-sea $\mathrm{CO}_{2}$ flux that was driven by other anthropogenically driven processes, such as coastal nutrient inputs and consequent enhanced productivity and burial of organic carbon. If we take our estimate of $\sim 0.1 \mathrm{Pg} \mathrm{C} \mathrm{yr}^{-1}$, and assume that it can be scaled in time with the increase in atmospheric $\mathrm{CO}_{2}$ concentrations, this might have caused an additional oceanic $\mathrm{C}$ storage of $10 \mathrm{Pg} \mathrm{C}$ over the industrial era that needs to be added to the global increase in oceanic storage.

In the global $\mathrm{CO}_{2}$ budget reported for instance by the IPCC and by the Global Carbon Project (Fig. 3a) the 'land residual sink' is deduced as a difference between fossil-fuel and land-use-change emissions of $\mathrm{C}$ and atmospheric accumulation and open-ocean uptake $e^{21,22,95}$, the ocean component being estimated from forward and inverse models ${ }^{21,96}$. This method implicitly assumes that the pre-anthropogenic global carbon budget was at steady state and the fluxes along the land-ocean aquatic continuum, unlike most other fluxes, have no anthropogenic component. Thus, these 'classical' budgets ignore the anthropogenic perturbation of the boundless carbon cycle displayed in Fig. 1c. Our new estimation of these fluxes allows us to deconvolute the 'land residual sink' into (1) a 'terrestrial ecosystem sink' of anthropogenic $\mathrm{CO}_{2}$ comprising the contribution of the land vegetation, litter, soils and the bedrock, and (2) sources and sinks of anthropogenic $\mathrm{CO}_{2}$ occurring in the aquatic ecosystems of the freshwater-estuarine-coastal ocean continuum (Fig. 3b). We find that the 'terrestrial ecosystem sink' in the boundless carbon cycle is removing $\sim 2.85 \mathrm{Pg} \mathrm{C} \mathrm{yr}^{-1}$ of anthropogenic $\mathrm{CO}_{2}$ from the atmosphere (Fig. 3b). This sink of $\mathrm{CO}_{2}$ is larger than the residual land sink estimates reported by the IPCC or the Global Carbon Project ${ }^{21}$ (Fig. 3a) because a fraction of this flux is returned to the atmosphere by $\mathrm{CO}_{2}$ outgassing along the ecosystems of the land-ocean aquatic continuum. However, only $0.9 \mathrm{Pg} \mathrm{C} \mathrm{yr}^{-1}$ of this terrestrial ecosystem sink is actually sequestered in biomass and soil of land ecosystems, as $1.0 \mathrm{Pg} \mathrm{C} \mathrm{yr}^{-1}$ is released to the atmosphere owing to land-use changes, and a similar amount $\left(1.0 \mathrm{Pg} \mathrm{C} \mathrm{yr}^{-1}\right)$ is exported to the land-ocean aquatic continuum. The net biomass and soil sequestration estimate calculated here is consistent with the 'bottom-up' estimates reported in Fig. 1c from biomass and soil-carbon inventories ${ }^{92}\left(0.8 \mathrm{Pg} \mathrm{C} \mathrm{yr}^{-1}\right)$, thus providing additional support to our independent estimation of the anthropogenic $\mathrm{C}$ delivered to the water continuum (see Supplementary Note). Enhanced rock weathering contributes also to the anthropogenic perturbation (Fig. 3b, $0.1 \mathrm{Pg} \mathrm{C} \mathrm{yr}^{-1}$ ). The anthropogenic $\mathrm{C}$ delivered to freshwaters is partly outgassed to the atmosphere as $\mathrm{CO}_{2}\left(0.55 \mathrm{Pg} \mathrm{C} \mathrm{yr}^{-1}\right)$, partly sequestered in sediments $\left(0.35 \mathrm{Pg} \mathrm{C} \mathrm{yr}^{-1}\right)$ and partly exported to the coastal ocean $\left(0.1 \mathrm{Pg} \mathrm{C} \mathrm{yr}^{-1}\right)$. The coastal ocean also contributes to the anthropogenic $\mathrm{CO}_{2}$ budget (0.2 $\mathrm{Pg} \mathrm{C} \mathrm{yr}^{-1}$ air-sea uptake, $0.2 \mathrm{Pg} \mathrm{C} \mathrm{yr}^{-1}$ sequestered in coastal sediments and water column). As a result, the land-ocean aquatic continuum is both a net source of anthropogenic $\mathrm{CO}_{2}$ to the atmosphere of $0.35 \mathrm{Pg} \mathrm{C} \mathrm{yr}^{-1}$ and a net anthropogenic $\mathrm{C}$ storage in sediments of $0.55 \mathrm{Pg} \mathrm{C} \mathrm{yr}^{-1}$ (Fig. 3b).

Of importance is the finding that the terrestrial ecosystem $\mathrm{CO}_{2}$ sink (2.85 $\left.\mathrm{Pg} \mathrm{C} \mathrm{yr}^{-1}\right)$ is more than three times larger than the terrestrial anthropogenic $\mathrm{C}$ stock increase $\left(0.9 \mathrm{Pg} \mathrm{C} \mathrm{yr}^{-1}\right)$ because of landuse changes, as already accounted in global carbon budgets, but also because of the lateral export of anthropogenic $\mathrm{C}$ from soils to inland waters. This distinction is important because processes that control the interannual variability and long-term evolution of the terrestrial stocks of $\mathrm{C}$ are different from those controlling the aquatic stocks and fluxes ${ }^{97}$. This also shows that more than half of the net 'sequestration service' (terrestrial ecosystem sink minus land-use change) from terrestrial ecosystems (mainly forest) is negated by leakage of carbon from soils to freshwater aquatic systems, and to the atmosphere. Therefore, from a $\mathrm{CO}_{2}$ budget point of view, the net land anthropogenic $\mathrm{CO}_{2}$ uptake from terrestrial, freshwater and estuarine aquatic ecosystems is only about $1.3 \mathrm{Pg} \mathrm{C} \mathrm{yr}^{-1}$, while the ocean uptake of anthropogenic $\mathrm{CO}_{2}$ (coastal and open ocean) is about $2.5 \mathrm{Pg} \mathrm{C} \mathrm{yr}^{-1}$. It is also important to stress that because of lateral transport of anthropogenic $\mathrm{C}$ by the boundless $\mathrm{C}$ cycle, the carbon storage changes ${ }^{15,98}$ in the different reservoirs of the land-ocean aquatic continuum are considerably different from the net $\mathrm{CO}_{2}$ fluxes exchanged with the atmosphere. Furthermore, the significant uncertainty on the aquatic continuum flux results in a larger uncertainty in the terrestrial ecosystem (and open ocean) carbon storage than what is reported in the traditional Global Carbon Project budget.

\section{Critical quantifications}

Although we have demonstrated that it is possible to establish closed $\mathrm{C}$ and anthropogenic $\mathrm{CO}_{2}$ budgets, broadly consistent with the current growth rate of atmospheric $\mathrm{CO}_{2}$, the component fluxes for the land-ocean aquatic continuum cannot be adequately quantified through a robust statistical treatment of available datasets yet. The data are also too sparse to resolve fully the diversity of soil types, inland waters, estuaries and coastal systems. In particular, wetland and riparian ecosystems lateral fluxes are not known. Nevertheless and importantly, revised anthropogenic $\mathrm{CO}_{2}$ budgets need to consider and assess quantitatively the anthropogenic perturbation to the aquatic continuum. Any improved estimates will certainly at least require a considerably denser carbon and $\mathrm{CO}_{2}$ flux observation system, based on direct measurements of $\mathrm{CO}_{2}$ gas-transfer velocities and ecosystem surface areas. These measurements should be completed by an expansion of $\mathrm{pCO}_{2}$ sampling and, in some cases, of flux towers into wetlands and aquatic systems, to have continuous monitoring. Areas of regional priority include the Amazon and the Congo riverine basins and their tropical coastal currents. The Ganges River system, the Bay of Bengal, the Indonesian Archipelago, the Southeast Asian 
seas and the Arctic rivers are other critical regions having significantly large carbon inputs into the coastal seas. Furthermore, a quantitative mechanistic understanding of the key processes controlling $\mathrm{CO}_{2}$ outgassing and preservation of $\mathrm{C}$ in the land-ocean continuum is needed. An important unknown involves knowledge of the sources, transport pathways and lability and rates of degradation of accumulating organic and inorganic $\mathrm{C}$, be it in soils, the aquatic system or the sea floor. The mechanistic understanding is necessary to parameterize the various processes involving $\mathrm{C}$ and their sensitivity to external perturbations at the larger scales of Earth system models. At present, this lack of understanding limits our ability to predict the present and future contribution of the aquatic continuum fluxes to the global $\mathrm{C}$ budget involving anthropogenic $\mathrm{CO}_{2}$.

Received 16 October 2012; accepted 23 April 2013; published online 9 June 2013

\section{References}

1. Likens, G. E., Mackenzie, F. T., Richey, J. E., Sedwell, J. R. \& Turekian, K. K. Flux of Organic Carbon from the Major Rivers of the World to the Oceans (National Technical Information Service, US Department of Commerce, 1981).

2. Mulholland, P. J. \& Elwood, J. W. The role of lake and reservoir sediments as sinks in the perturbed global carbon cycle. Tellus 34, 490-499 (1982).

3. Wollast, R. \& Mackenzie, F. T. in Climate and Geo-sciences Vol. 285 (eds Berger, A., Schneider, S. \& Duplessy, J. Cl.) 453-473 (Academic Publishers, 1989).

4. Degens, E. T., Kempe, S. \& Richey, J. E. Biogeochemistry of Major World Rivers. (Wiley, 1991).

5. Smith, S. V. \& Hollibaugh, J. T. Coastal metabolism and the oceanic organic carbon balance. Rev. Geophys. 31, 75-89 (1993).

6. Stallard, R. F. Terrestrial sedimentation and the carbon cycle: coupling weathering and erosion to carbon burial. Glob. Biogeochem. Cycles 12, 231-257 (1998).

7. Ver, L. M. B., Mackenzie, F. T. \& Lerman, A. Biogeochemical responses of the carbon cycle to natural and human perturbations: past, present, and future. Am. J. Sci. 299, 762-801 (1999).

8. Richey, J. E. in The Global Carbon Cycle, Integrating Humans, Climate, and the Natural World Vol. 17 (eds Field, C. B. \& Raupach, M. R.) 329-340 (Island Press, 2004).

9. Raymond, P. A., Oh, N. H., Turner, R. E. \& Broussard, W. Anthropogenically enhanced fluxes of water and carbon from the Mississippi River. Nature 451, 449-452 (2008).

10. Aumont, O. et al. Riverine-driven interhemispheric transport of carbon. Glob. Biogeochem. Cycles 15, 393-405 (2001).

11. Global nutrient exports from watersheds. Glob. Biogeochem. Cycles 19 (special issue), no. 4 (2005).

12. Mackenzie, F. T., Andersson, A. J., Lerman, A. \& Ver, L. M. in The Sea Vol. 13 (eds Robinson, A. R. \& Brink, K. H.) 193-225 (Harvard Univ. Press, 2005).

13. Cotrim da Cunha, L., Buitenhuis, E. T., Le Quéré, C., Giraud, X. \& Ludwig, W. Potential impact of changes in river nutrient supply on global ocean biogeochemistry. Glob. Biogeochem. Cycles 21, GB4007 (2007).

14. Quinton, J. N., Govers, G., Van Oost, K. \& Bardgett, R. D. The impact of agricultural soil erosion on biogeochemical cycling. Nature Geosci. 3, 311-314 (2010).

15. Sarmiento, J. L. \& Sundquist, E. T. Revised budget for the oceanic uptake of anthropogenic carbon dioxide. Nature 356, 589-593 (1992).

16. Cole, J. J. et al. Plumbing the global carbon cycle: integrating inland waters into the terrestrial carbon budget. Ecosystems 10, 171-184 (2007).

17. Battin, T. J. et al. The boundless carbon cycle. Nature Geosci. 2, 598-600 (2009).

18. McLeod, E. et al. A blueprint for blue carbon: toward an improved understanding of the role of vegetated coastal habitats in sequestering $\mathrm{CO}_{2}$. Front. Ecol. Environ. 9, 552-560 (2011).

19. Sarmiento, J. L. \& Gruber, N. Sinks for anthropogenic carbon. Phys. Today 55, 30-36 (August 2002)

20. Denman, K. L. et al. in IPCC Climate Change 2007: The Physical Science Basis (eds Solomon, S. et al.) 499-588 (Cambridge Univ. Press, 2007).

21. Le Quéré, C. et al. Trends in the sources and sinks of carbon dioxide. Nature Geosci. 2, 831-836 (2009).

22. Peters, G. P. et al. Rapid growth in $\mathrm{CO}_{2}$ emissions after the 2008-2009 global financial crisis. Nature Clim. Change 2, 2-4 (2012).

23. Global Carbon Project.Carbon Budget and Trends 2012 www.globalcarbonproject.org/carbonbudget (2012).

24. Ludwig, W. \& Probst, J. L. River sediment discharge to the oceans: present-day controls and global budgets. Am. J. Sci. 298, 265-295 (1998).

25. Archer, D. Fate of fossil fuel $\mathrm{CO}_{2}$ in geologic time. J. Geophys. Res.-Oceans $110,1-6(2005)$
26. Tranvik, L. J. et al. Lakes and reservoirs as regulators of carbon cycling and climate. Limnol. Oceanogr. 54, 2298-2314 (2009).

27. Laruelle, G. G., Dürr, H. H., Slomp, C. P. \& Borges, A. V. Evaluation of sinks and sources of $\mathrm{CO}_{2}$ in the global coastal ocean using a spatially-explicit typology of estuaries and continental shelves. Geophys. Res. Lett. 37, L15607 (2010).

28. Collins, W. J. et al. Development and evaluation of an Earth-system model HadGEM2. Geosci. Model Dev. Discuss. 4, 997-1062 (2011).

29. Ciais, P. et al. Geo Carbon Strategy (Geo Secretariat Geneva/Food and Agriculture Organization, 2010).

30. Bastviken, D., Tranvik, L. J., Downing, J. A., Crill, P. M. \& Enrich-Prast, A. Freshwater methane emissions offset the continental carbon sink. Science 331, 50 (2011).

31. Ittekkot, V., Humborg, C., Rahm, L. \& Nguyen, T. A. in Interactions of the Major Biogeochemical Cycles: Global Change and Human Impacts Vol. 357 (eds Melillo, J. M., Field, C. B. \& Moldan, B.) Ch. 17, 311-322 (Island Press, 2004).

32. Luyssaert, $\mathrm{S}$. et al. $\mathrm{CO}_{2}$ balance of boreal, temperate, and tropical forests derived from a global database. Glob. Change Biol. 13, 2509-2537 (2007).

33. Garrels, R. M. \& MacKenzie, F. T. Evolution of Sedimentary Rocks (Norton, 1971).

34. Holland, H. D. The chemistry of the atmosphere and oceans (Wiley, 1978).

35. Gaillardet, J., Dupré, B., Louvat, P. \& Allègre, C. J. Global silicate weathering and $\mathrm{CO}_{2}$ consumption rates deduced from the chemistry of large rivers. Chem. Geol. 159, 3-30 (1999)

36. Munhoven, G. Glacial-interglacial changes of continental weathering: estimates of the related $\mathrm{CO}_{2}$ and $\mathrm{HCO}_{3}$-flux variations and their uncertainties. Glob. Planet. Change 33, 155-176 (2002).

37. Hartmann, J., Jansen, N., Dürr, H. H., Kempe, S. \& Köhler, P. Global $\mathrm{CO}_{2}$ consumption by chemical weathering: What is the contribution of highly active weathering regions? Glob. Planet. Change 69, 185-194 (2009).

38. Mackenzie, F. T. \& Lerman, A. Carbon in the Geobiosphere - Earth's Outer Shell (Springer, 2006).

39. Kempe, S. in Transport of Carbon and Minerals in Major World Rivers Part 1 (ed. Degens, E. T.) 91-332 (Mitt. Geol.-Paläont. Inst. Univ. Hamburg, SCOPE/UNEP Sonderband, 1982).

40. Prairie, Y. T. \& Duarte, C. M. Direct and indirect metabolic $\mathrm{CO}_{2}$ release by humanity. Biogeosciences 4, 215-217 (2007).

41. Mackenzie, F. T., Lerman, A. \& Ver, L. M. in Geological Perspectives of Global Climate Change. AAPG Studies in Geology Vol. 47 (eds Gerhard, L. C., Harrison, W. E. \& Hanson, B. M.) 51-82 (American Association of Petroleum Geologists, 2001).

42. Cole, J. J., Caraco, N. F., Kling, G. W. \& Kratz, T. K. Carbon dioxide supersaturation in the surface waters of lakes. Science 265, 1568-1570 (1994).

43. Downing, J. A. et al. Sediment organic carbon burial in agriculturally eutrophic impoundments over the last century. Glob. Biogeochem. Cycles 22, GB1018 (2008)

44. Raymond, P. A. \& Bauer, J. E. Use of ${ }^{14} \mathrm{C}$ and ${ }^{13} \mathrm{C}$ natural abundances for evaluating riverine, estuarine, and coastal DOC and POC sources and cycling: a review and synthesis. Org. Geochem. 32, 469-485 (2001).

45. Bianchi, T. S. The role of terrestrially derived organic carbon in the coastal ocean: a changing paradigm and the priming effect. Proc. Natl Acad. Sci. USA 108, 19473-19481 (2011).

46. Stets, E. G., Striegl, R. G., Aiken, G. R., Rosenberry, D. O. \& Winter, T. C. Hydrologic support of carbon dioxide flux revealed by whole-lake carbon budgets. J. Geophys. Res.-Biogeosciences 114, G1 (2009).

47. Meybeck, M. Carbon, nitrogen, and phosphorus transport by world rivers. Am. J. Sci. 282, 401-450 (1982).

48. Copard, Y., Amiotte-Suchet, P. \& Di-Giovanni, C. Storage and release of fossil organic carbon related to weathering of sedimentary rocks. Earth Planet. Sci. Lett. 258, 345-357 (2007).

49. Galy, V. et al. Efficient organic carbon burial in the Bengal fan sustained by the Himalayan erosional system. Nature 450, 407-410 (2007).

50. Sobek, S., Tranvik, L. J. \& Cole, J. J. Temperature independence of carbon dioxide supersaturation in global lakes. Glob. Biogeochem. Cycles 19, 1-10 (2005).

51. Butman, D. \& Raymond, P. A. Significant efflux of carbon dioxide from streams and rivers in the United States. Nature Geosci. 4, 839-842 (2011).

52. Sobek, S., Tranvik, L. J., Prairie, Y. T., Kortelainen, P. \& Cole, J. J. Patterns and regulation of dissolved organic carbon: an analysis of 7,500 widely distributed lakes. Limnol. Oceanogr. 52, 1208-1219 (2007).

53. Humborg, C. et al. $\mathrm{CO}_{2}$ supersaturation along the aquatic conduit in Swedish watersheds as constrained by terrestrial respiration, aquatic respiration and weathering. Glob. Change Biol. 16, 1966-1978 (2010).

54. Richey, J. E., Melack, J. M., Aufdenkampe, A. K., Ballester, V. M. \& Hess, L. L. Outgassing from Amazonian rivers and wetlands as a large tropical source of atmospheric $\mathrm{CO}_{2}$. Nature 416, 617-620 (2002).

55. Melack, J. M., Novo, E. M. L. M., Forsberg, B. R., Piedade, M. T. F. \& Maurice, L. in Amazonia and Global Change (eds Keller, M., Bustamante, M., Gash, J. \& Silva Dias, P.) 525-541 (Geophysical Monograph Series Vol. 186, AGU, 2009). 
56. Smith, S. V., Renwick, W. H., Buddemeier, R. W. \& Crossland, C. J. Budgets of soil erosion and deposition for sediments and sedimentary organic carbon across the conterminous United States. Glob. Biogeochem. Cycles 15, 697-707 (2001).

57. Aufdenkampe, A. K. et al. Riverine coupling of biogeochemical cycles between land, oceans, and atmosphere. Front. Ecol. Environ. 9, 53-60 (2011).

58. Meybeck, M. in Interactions of C, N, P and S: Biogeochemical Cycles (eds Wollast, R., Mackenzie, F. T. \& Chou, L.) 163-193 (Springer Verlag, 1991).

59. Beusen, A. H. W., Dekkers, A. L. M., Bouwman, A. F., Ludwig, W. \& Harrison, J. Estimation of global river transport of sediments and associated particulate C, N, and P. Glob. Biogeochem. Cycles 19, GB4S05 (2005).

60. Schlesinger, W. H. \& Melack, J. M. Transport of organic carbon in the world's rivers. Tellus 33, 172-187 (1981)

61. Degens, E. T. in Transport of Carbon and Minerals in Major World Rivers, Part $1 S$ Vol. 52 (ed. Degens, E. T.) 1-12 (Mitt. Geol.-Paläont. Inst. Univ. Hamburg, SCOPE/UNEP Sonderband, 1982).

62. Laruelle, G. G. et al. Global multi-scale segmentation of continental and coasta waters from the watersheds to the continental margins. Hydrol. Earth Syst. Sci. 17, 2029-2051 (2012).

63. Cai, W. J. Estuarine and coastal ocean carbon paradox: $\mathrm{CO}_{2}$ sinks or sites of terrestrial carbon incineration? Ann. Rev. Mar. Sci. 3, 123-145 (2011).

64. Borges, A. V. \& Abril, G. in Treatise on Estuarine and Coastal Science Vol. 5 (eds Wolanski, E. \& McLusky, D. S.) 119-161 (Academic Press, 2012).

65. Duarte, C. M., Middelburg, J. J. \& Caraco, N. Major role of marine vegetation on the oceanic carbon cycle. Biogeosciences 2, 1-8 (2005)

66. Breithaupt, J. L., Smoak, J. M., Smith, T. J., Sanders, C. J. \& Hoare, A. Organic carbon burial rates in mangrove sediments: strengthening the global budget. Glob. Biogeochem. Cycles 26, GB3011 (2012).

67. Cai, W. J., Dai, M. \& Wang, Y. Air-sea exchange of carbon dioxide in ocean margins: a province-based synthesis. Geophys. Res. Lett. 33, L12603 (2006).

68. Borges, A. V., Delille, B. \& Frankignoulle, M. Budgeting sinks and sources of $\mathrm{CO}_{2}$ in the coastal ocean: diversity of ecosystem counts. Geophys. Res. Lett. 32, 1-4 (2005)

69. Wanninkhof, R. et al. Global ocean carbon uptake: magnitude, variability and trends. Biogeosci. Discuss. 9, 10961-11012 (2012).

70. Liu, K. K., Atkinson, L., Quiñones, R. \& Talaue-McManus, L. Carbon and Nutrient Fluxes in Continental Margins: A Global Synthesis (Springer, 2010).

71. Muller-Karger, F. E. et al. The importance of continental margins in the global carbon cycle. Geophys. Res. Lett. 32, L01602 (2005).

72. Krumins, V., Gehlen, M., Arndt, S., Van Cappellen, P. \& Regnier, P. Dissolved inorganic carbon and alkalinity fluxes from coastal marine sediments: model estimates for different shelf environments and sensitivity to global change. Biogeosciences 10, 371-398 (2013).

73. Dunne, J. P., Sarmiento, J. L. \& Gnanadesikan, A. A synthesis of global particle export from the surface ocean and cycling through the ocean interior and on the seafloor. Glob. Biogeochem. Cycles 21, GB4006 (2007).

74. Andersson, A. J., MacKenzie, F. T. \& Lerman, A. Coastal ocean and carbonate systems in the high $\mathrm{CO}_{2}$ world of the anthropocene. Am. J. Sci. 305, 875-918 (2005).

75. Blair, N. E. \& Aller, R. C. The fate of terrestrial organic carbon in the marine environment. Ann. Rev. Mar. Sci. 4, 401-423 (2012).

76. Mackenzie, F. T., De Carlo, E. H. \& Lerman, A. in Treatise on Estuarine and Coastal Science (eds Middelburg, J. J. \& Laane, R.) Ch. 5.10 (Elsevier, 2012).

77. Jahnke, R. in Carbon and Nutrient Fluxes in Continental Margins, Global Change - The IGBP Series Vol. 3 (eds Liu, K-K. et al.) 597-615 (Verlag, 2010).

78. Milliman, J. \& Meade, R. World-wide delivery of river sediment to the oceans. J. Geol. 91, 1-21 (1983).

79. Van Oost, K. et al. The impact of agricultural soil erosion on the global carbon cycle. Science 318, 626-629 (2007)

80. Billings, S. A., Buddemeier, R. W., Richter, D. deB., Van Oost, K. \& Bohling G. A simple method for estimating the influence of eroding soil profiles on atmospheric $\mathrm{CO}_{2}$. Glob. Biogeochem. Cycles 24, GB2001 (2010).

81. Mackenzie, F. T., Ver, L. M. \& Lerman, A. Century-scale nitrogen and phosphorus controls of the carbon cycle. Chem. Geol. 190, 13-32 (2002).

82. Gislason, S. R. et al. Direct evidence of the feedback between climate and weathering. Earth Planet. Sci. Lett. 277, 213-222 (2009).

83. Beaulieu, E., Goddëris, Y., Donnadieu, Y., Labat, D. \& Roelandt, C. High sensitivity of the continental-weathering carbon dioxide sink to future climate change. Nature Clim. Change 2, 346-349 (2012).

84. Bayon, G. et al. Intensifying weathering and land use in iron age Central Africa. Science 335, 1219-1222 (2012)

85. Oh, N. H. \& Raymond, P. A. Contribution of agricultural liming to riverine bicarbonate export and $\mathrm{CO}_{2}$ sequestration in the Ohio River basin. Glob. Biogeochem. Cycles 20, GB3012 (2006).

86. Hamilton, S. K., Kurzman, A. L., Arango, C., Jin, L. \& Robertson, G. P. Evidence for carbon sequestration by agricultural liming. Glob. Biogeochem. Cycles 21, GB2021 (2007).
87. Lerman, A., Mackenzie, F. T. \& Ver, L. M. Coupling of the perturbed C-N-P cycles in industrial time. Aquat. Geochem. 10, 3-32 (2004).

88. Seitzinger, S. P., Harrison, J. A., Dumont, E., Beusen, A. H. W. \& Bouwman, A. F. Sources and delivery of carbon, nitrogen, and phosphorus to the coastal zone: an overview of Global Nutrient Export from Watersheds (NEWS) models and their application. Glob. Biogeochem. Cycles 19, GB4S01 (2005).

89. Gruber, N. \& Galloway, J. N. An Earth-system perspective of the global nitrogen cycle. Nature 451, 293-296 (2008).

90. Jin, X., Gruber, N., Frenzel, H., Doney, S. C. \& McWilliams, J. C. The impact on atmospheric $\mathrm{CO}_{2}$ of iron fertilization induced changes in the ocean's biological pump. Biogeosciences 5, 385-406 (2008).

91. Guenet, B., Danger, M., Abbadie, L. \& Lacroix, G. Priming effect: bridging the gap between terrestrial and aquatic ecology. Ecology 91, 2850-2861 (2010).

92. Pan, Y. et al. A large and persistent carbon sink in the world's forests. Science 333, 988-993 (2011).

93. Jacobson, A. R., Fletcher, S. E. M., Gruber, N., Sarmiento, J. L. \& Gloor, M. A joint atmosphere-ocean inversion for surface fluxes of carbon dioxide: 1. Methods and global-scale fluxes. Glob. Biogeochem. Cycles 21, GB1020 (2007).

94. Khatiwala, S. et al. Global ocean storage of anthropogenic carbon. Biogeosci. Discuss. 9, 8931-8988 (2012).

95. Friedlingstein, P. et al. Update on $\mathrm{CO}_{2}$ emissions. Nature Geosci. 3, 811-812 (2010)

96. Sarmiento, J. L. et al. Trends and regional distributions of land and ocean carbon sinks. Biogeosciences 7, 2351-2367 (2010)

97. Yvon-Durocher, G. et al. Reconciling the temperature dependence of respiration across timescales and ecosystem types. Nature 487, 472-476 (2012).

98. Tans, P. P., Fung, I. Y. \& Enting, I. G. in Biotic Feedbacks in the Global Climatic System: Will the Warming Feed the Warming? (eds Woodwell, G. M. \& Mackenzie, F. T.) 351-366 (Oxford Univ. Press, 1995).

99. King, A. W. et al. The First State of the Carbon Cycle Report (SOCCR): The North American Carbon Budget and Implications for the Global Carbon Cycle (US Climate Change Science Program, 2007).

100. Meybeck, M., Dürr, H. H. \& Vörösmarty, C. J. Global coastal segmentation and its river catchment contributors: a new look at land-ocean linkage. Glob. Biogeochem. Cycles 20, GB1S90 (2006).

\section{Acknowledgements}

This paper is the outcome of the workshop 'Exploring knowledge gaps along the global carbon route: a hitchhiker's guide for a boundless cycle' held in Eprave, Belgium, in November 2011. The authors would like to thank S. Bonneville, L. Chou, P. Cox, H. Durr, T. Eglinton, K. Fleischer, J. Kaplan, T. Kleinen, D. Dan Li, A. Mouchet, H. Nick, C. Pallud, C. Prentice, D. Schimel, M. Serrano, J-L. Tison, P. Van Cappellen, C. Volta and J. Zhou for their input during the workshop. The workshop was officially endorsed by the Global Carbon Project (GCP) and by the Analysis, Integration and Modeling of the Earth System (AIMES) of the International Geosphere-Biosphere Programme (IGBP) and received financial support from the government of the Brussels-Capital region (Innoviris - Brains Back to Brussels award to P.R.), the Walloon Agency for Air and Climate (AWAC), the Fonds National de la Recherche Scientifique of Belgium (FNRS), The Belgian Federal Science Policy Office (BELSPO), the Université Libre de Bruxelles (Belgium), the Netherlands Organization for Scientific Research (NWO), the King Abdullah University of Science and Technology (KAUST) Center-in-Development Award to Utrecht University (The Netherlands), the University of Waterloo (Canada) and the University of Exeter (UK). The research leading to these results received funding from the European Union's Seventh Framework Program (FP7/2007-2013) under grant agreement number 283080, project GEOCARBON.

\section{Author contributions}

P.R. and P.F. initiated the Eprave workshop that led to this paper. P.R. coordinated and participated at all stages of the conception and writing of the paper. P.F., P.C., F.T.M. and N.G. were central to the conception of the paper and to the writing of the manuscript. I.A.J proposed the overall design of Fig. 3. G.G.L. and R.L. produced Fig. 2, using the GloRiCh database for inland waters assembled by J. Hartmann and co-workers. S.L. took a leading role in the quantification of the terrestrial ecosystem budget. All other authors contributed to specific aspects of the budget analysis and commented on various versions of the manuscript. F.T.M. was instrumental to the genesis of this paper through his pioneering work in the field.

\section{Additional information}

Supplementary information accompanies this paper on www.nature.com/geoscience. Reprints and permission information is available online at www.nature.com/reprints. Correspondence and requests for materials should be addressed to P.R.

\section{Competing financial interests}

The authors declare no competing financial interests. 
Pierre Regnier ${ }^{1 \star}$, Pierre Friedlingstein ${ }^{2}$, Philippe Ciais ${ }^{3}$, Fred T. Mackenzie ${ }^{4}$, Nicolas Gruber ${ }^{5}$, Ivan A. Janssens ${ }^{6}$, Goulven G. Laruelle', Ronny Lauerwald ${ }^{17}$, Sebastiaan Luyssaert ${ }^{3}$, Andreas J. Andersson ${ }^{8}$, Sandra Arndt ${ }^{9}$, Carol Arnosti ${ }^{10}$, Alberto V. Borges ${ }^{11}$, Andrew W. Dale ${ }^{12}$, Angela Gallego-Sala ${ }^{13}$, Yves Goddéris ${ }^{14}$, Nicolas Goossens ${ }^{1}$, Jens Hartmann ${ }^{7}$, Christoph Heinze ${ }^{15,16,17}$, Tatiana llyina ${ }^{18}$, Fortunat Joos ${ }^{19}$, Douglas E. LaRowe ${ }^{20}$, Jens Leifeld ${ }^{21}$, Filip J. R. Meysman ${ }^{22,23}$, Guy Munhoven ${ }^{24}$, Peter A. Raymond ${ }^{25}$, Renato Spahni ${ }^{19}$, Parvadha Suntharalingam ${ }^{26}$ and Martin Thullner ${ }^{27}$

\footnotetext{
'Department of Earth and Environmental Sciences, CP160/02, Université Libre de Bruxelles, 1050 Bruxelles, Belgium, ${ }^{2}$ College of Engineering, Mathematics and Physical Sciences, University of Exeter, Exeter EX4 4QF, UK, ${ }^{2}$ Laboratoire des Sciences du Climat et l'Environnement, 91190 Gif-sur-Yvette, France, ${ }^{4}$ Department of Oceanography, School of Ocean and Earth Science and Technology, University of Hawai'i at Mãnoa, Honolulu, Hawaii 96822, USA, ${ }^{5}$ Environmental Physics, Institute of Biogeochemistry and Pollutant Dynamics, Department of Environmental Sciences, ETH Zürich, 8092 Zurich, Switzerland, ' Departement Biologie, Universiteit Antwerpen, 2160 Wilrijk, Belgium, ${ }^{7}$ Institute for Biogeochemistry and Marine Chemistry, KlimaCampus, D-20146 Hamburg, Germany, ${ }^{8}$ Scripps Institution of Oceanography, University of California San Diego, La Jolla, California 92093-0202, USA, ${ }^{9}$ School of Geographical Sciences, University of Bristol, University Road, Bristol BS8 1SS, UK, ${ }^{10}$ Department of Marine Sciences, University of North Carolina, Chapel Hill, North Carolina 27599, USA, "University of Liège, Chemical Oceanography Unit, Institut de Physique (B5), B-4000 Liège, Belgium, ${ }^{12}$ GEOMAR Helmholtz-Zentrum für Ozeanforschung Kiel, Wischhofstraße 1-3, 24148 Kiel, Germany, 13Department of Geography, University of Exeter, Exeter EX4 4RJ, UK, ${ }^{14}$ Géosciences Environnement Toulouse, Centre National de la Recherche Scientifique, Observatoire Midi-Pyrénées, Université Toulouse III, 31400 Toulouse, France, ${ }^{15}$ Geophysical Institute, University of Bergen, N-5007 Bergen, Norway, ${ }^{16}$ Bjerknes Centre for Climate Research, N-5007 Bergen, Norway, ${ }^{17}$ Uni Bjerknes Centre, Uni Research, N-5007 Bergen, Norway, ${ }^{18}$ Max Planck Institute for Meteorology, 20146 Hamburg, Germany, ${ }^{19} \mathrm{Climate}$ and Environmental Physics, Physics Institute, and Oeschger Centre for Climate Change Research, University of Bern, Bern CH3012, Switzerland, ${ }^{20}$ Department of Earth Sciences, University of Southern California, Los Angeles, California 90089, USA, ${ }^{21}$ Agroscope Research Station ART, Reckenholzstrasse 191, 8046 Zurich, Switzerland, ${ }^{22}$ Royal Netherlands Institute of Sea Research, 4401 NT Yerseke, The Netherlands, ${ }^{23}$ Department of Analytical and Environmental Chemistry, Vrije Universiteit Brussel, 1050 Brussel, Belgium, ${ }^{24}$ Laboratoire de Physique Atmosphérique et Planétaire, Université de Liège, B-4000 Liège, Belgium, ${ }^{25}$ Yale School of Forestry and Environmental Studies, New Haven, Connecticut 06511, USA, ${ }^{26}$ School of Environmental Sciences, University of East Anglia, Norwich, NR4 7TJ, UK, ${ }^{27}$ Department of Environmental Microbiology, Helmholtz Centre for Environmental Research, Leipzig 04318, Germany.

*e-mail: pregnier@ulb.ac.be
} 